Prepared in cooperation with the U.S. ARMY CORPS OF ENGINEERS, TULSA DISTRICT

\title{
Gravel Sources for the Neosho River in Kansas, 2004
}

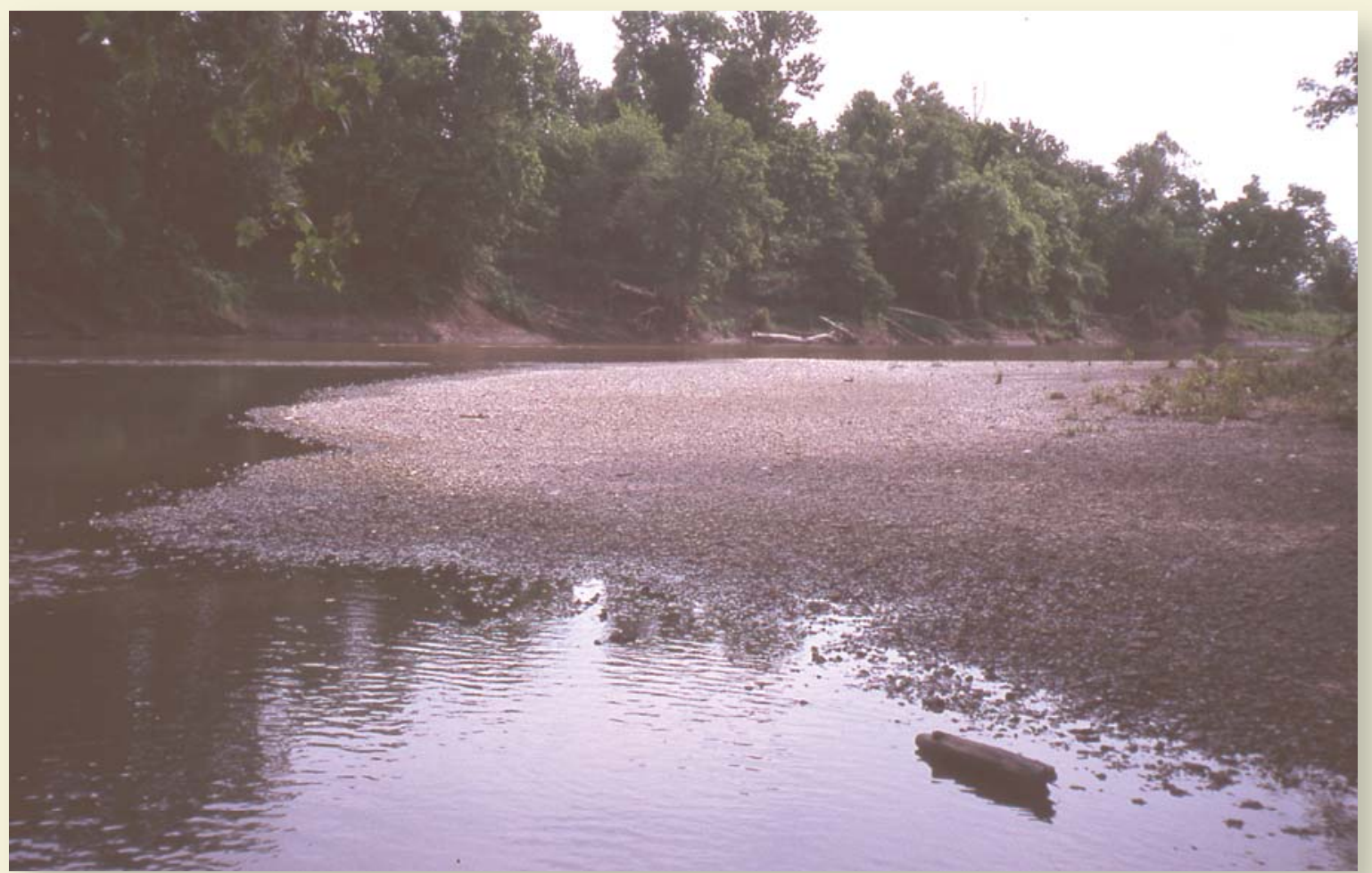

Scientific Investigations Report 2005-5282 


\section{Gravel Sources for the Neosho River in Kansas, 2004}

By Kyle E. Juracek and Charles A. Perry

Scientific Investigations Report 2005-5282 


\title{
U.S. Department of the Interior Gale A. Norton, Secretary
}

\author{
U.S. Geological Survey \\ P. Patrick Leahy, Acting Director
}

\section{U.S. Geological Survey, Reston, Virginia: 2005}

\author{
For sale by U.S. Geological Survey, Information Services \\ Box 25286, Denver Federal Center \\ Denver, CO 80225 \\ For more information about the USGS and its products: \\ Telephone: 1-888-ASK-USGS \\ World Wide Web: http://www.usgs.gov/
}

Any use of trade, product, or firm names in this publication is for descriptive purposes only and does not imply endorsement by the U.S. Government.

Although this report is in the public domain, permission must be secured from the individual copyright owners to reproduce any copyrighted materials contained within this report.

Suggested citation:

Juracek, K.E., and Perry, C.A., 2005, Gravel sources for the Neosho River in Kansas, 2004: U.S. Geological Survey Scientific Investigations Report 2005-5282, 36 p. 


\section{Contents}

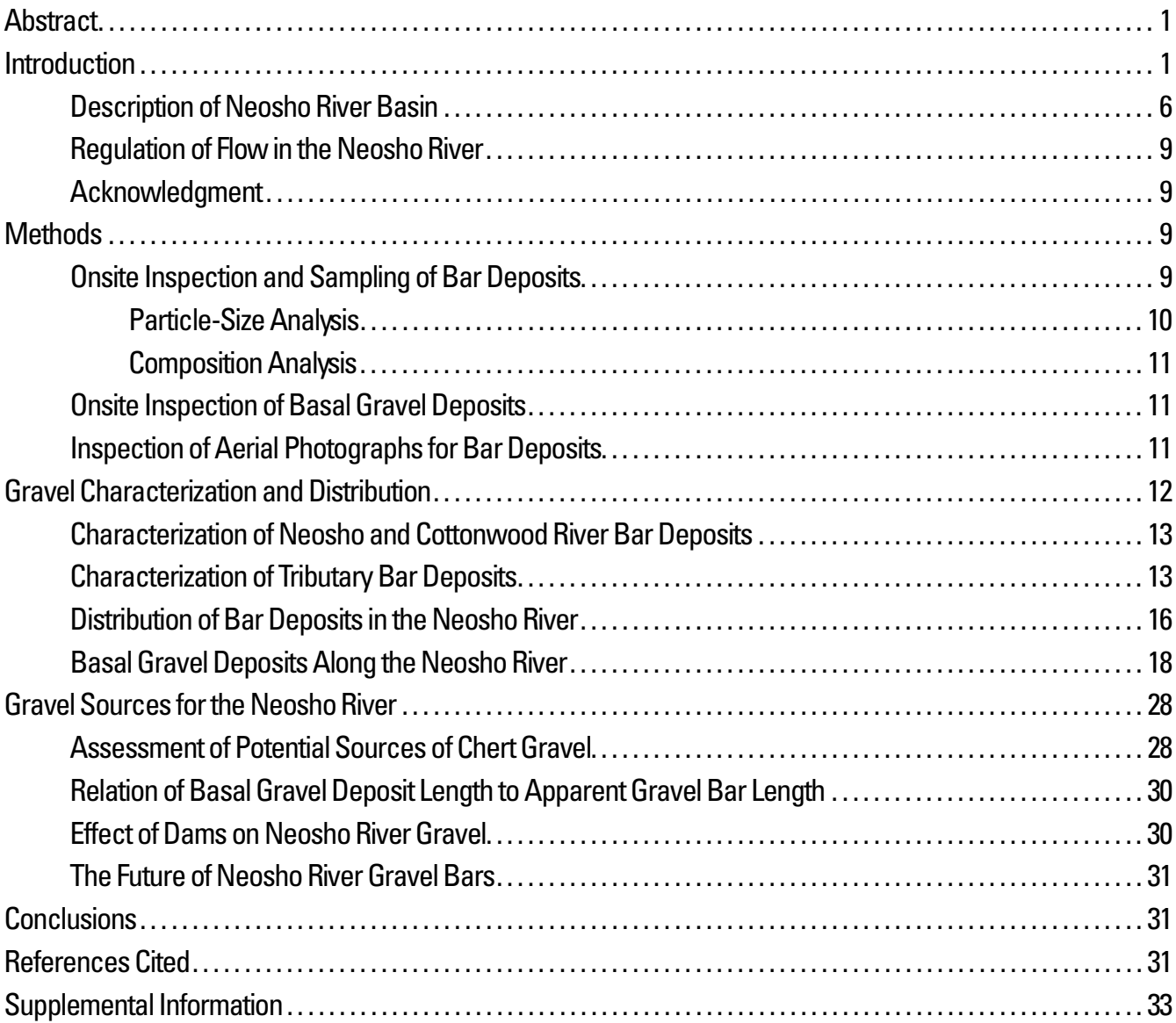

\section{Figures}

1. Maps showing location of Neosho River Basin in Kansas, John Redmond Reservoir, major tributaries, sampling sites, U.S. Geological Survey streamflow-gaging stations, inspection sites, and overflow

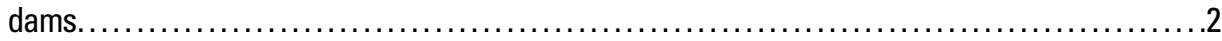

2. Map showing physiography of Kansas in relation to the Neosho River Basin..................5

3. Map showing approximate distribution of the Olpe soil in uplands of eastern Kansas. . ............. 7

4. Photographs of an upland gravel pit west of Colony, Kansas, and a closeup of chert gravel at

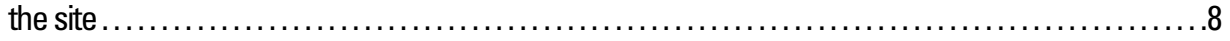

5. Photograph showing collection of a random sample of gravel for subsequent particle-size

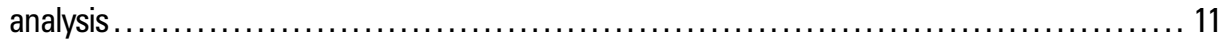

6. Photograph showing longest, intermediate, and shortest axes of a gravel particle ............ 12

7. Aerial and ground photographs of gravel bar sampled at site B-1 in Neosho River southeast of

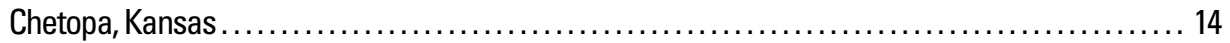

8. Aerial and ground photographs of gravel bar sampled at site B-8 in Neosho River south of

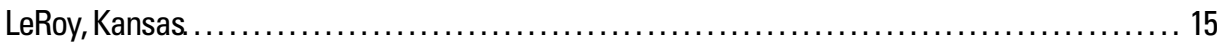

9. Photographs showing closeup of chert in gravel bars sampled at sites $B-1, B-8$, and $B-10$ in the Neosho River. 
10. Aerial photographs showing comparison of bar-deposit shapes in the Neosho River near LeRoy, Kansas, December 3, 2004.

11-17. Map showing distribution of exposed basal gravel deposits and apparent gravel bars in the Neosho River for the representative reach located near:

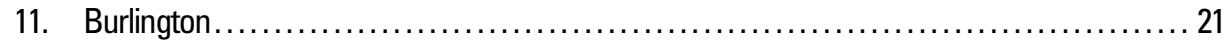

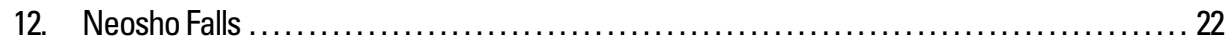

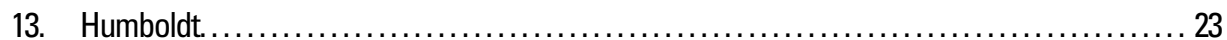

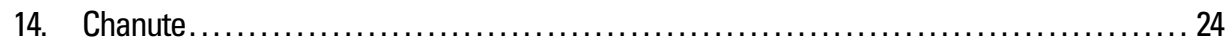

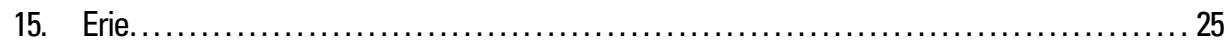

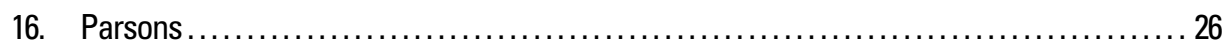

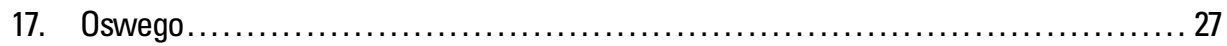

18. Photograph of basal gravel deposit exposed on a cutbank located on opposite side of the Neosho

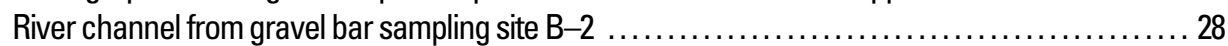

19. Aerial photograph of gravel bar in the Neosho River at its confluence with Indian Creek ......... 29

20. Graph showing relation between total basal gravel deposit length and total apparent gravel bar length for the seven Neosho River reaches inspected ............................... 30

\section{Tables}

1. Neosho River tributaries in Kansas inspected for gravel and the number of sites inspected for each

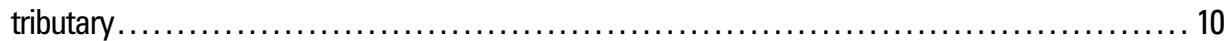

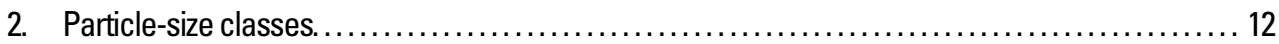

3. Chert content and particle-size data for gravel in bar deposits sampled in the Neosho and Cottonwood Rivers, Kansas, 2004............................................ 16

4. Neosho River tributaries in Kansas inspected for gravel, number of sites inspected for each tributary,

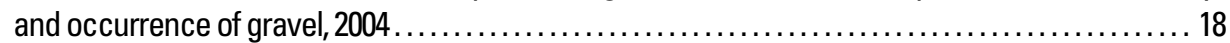

5. River reach length and approximate total length, extent, range in maximum thickness, and mean maximum thickness of exposed basal gravel deposits in channel banks of the Neosho River in Kansas

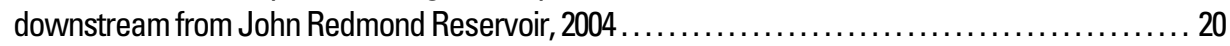

6. Particle-size data for gravel in bar deposits sampled in selected tributaries to the Neosho River in

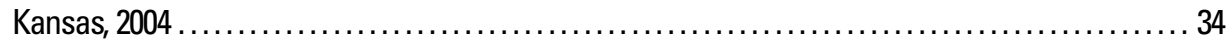




\section{Conversion Factors, Abbreviations, and Datums}

\begin{tabular}{lcl}
\hline Multiply & By & To obtain \\
\hline acre-foot (acre-ft) & 1,233 & cubic meter $\left(\mathrm{m}^{3}\right)$ \\
cubic foot per second $\left(\mathrm{ft}^{3} / \mathrm{s}\right)$ & 0.02832 & cubic meter per second $\left(\mathrm{m}^{3} / \mathrm{s}\right)$ \\
foot (ft) & 0.3048 & meter $(\mathrm{m})$ \\
foot per mile (ft/mi) & 0.1894 & meter per kilometer $(\mathrm{m} / \mathrm{km})$ \\
inch (in.) & 2.54 & centimeter $(\mathrm{cm})$ \\
mile (mi) & 1.609 & kilometer $(\mathrm{km})$ \\
millimeter $(\mathrm{mm})$ & 0.03937 & inch (in.) \\
square mile $\left(\mathrm{mi}^{2}\right)$ & 259.0 & hectare $(h a)$ \\
square mile $\left(\mathrm{mi}^{2}\right)$ & 2.590 & square kilometer $\left(\mathrm{km}^{2}\right)$ \\
\hline
\end{tabular}

Temperature in degrees Celsius $\left({ }^{\circ} \mathrm{C}\right)$ may be converted to degrees Fahrenheit $\left({ }^{\circ} \mathrm{F}\right)$ as follows:

${ }^{\circ} \mathrm{F}=\left(1.8 \mathrm{x}^{\circ} \mathrm{C}\right)+32$.

Temperature in degrees Fahrenheit $\left({ }^{\circ} \mathrm{F}\right)$ may be converted to degrees Celsius $\left({ }^{\circ} \mathrm{C}\right)$ as follows:

${ }^{\circ} \mathrm{C}=\left({ }^{\circ} \mathrm{F}-32\right) / 1.8$.

Horizontal coordinate information is referenced to the North American Datum of 1983 (NAD 83).

Vertical coordinate information is referenced to the North American Vertical Datum of 1988

(NAVD 88). 


\title{
Gravel Sources for the Neosho River in Kansas, 2004
}

\author{
By Kyle E. Juracek and Charles A. Perry
}

\section{Abstract}

Gravel (rock fragments ranging from 2 to 64 millimeters in size) is important in the Neosho River Basin of southeastern Kansas both as a resource for human needs and as habitat for the Neosho madtom, a threatened and endangered species of catfish. Concerns about the depletion of the gravel resource, because of natural processes, the construction of John Redmond Reservoir, and in-channel extraction, have prompted a need for information on possible sources of gravel replenishment along the Neosho River in Kansas. In 2004, a combination of onsite inspection, sampling, and aerial photography was used to assess the potential of tributaries and main-stem basal deposits as sources of gravel for the Neosho River.

Gravel in bar deposits of the Neosho River was consistent both in terms of composition and size. The gravel consisted primarily of brownish, rounded chert that was typically medium to coarse grained in size. A spatially representative inspection of 18 tributaries to the Neosho River indicated that, with one possible exception, the tributaries do not provide substantial inputs of chert gravel to the river. Inspection of seven representative reaches of the Neosho River indicated a statistically significant relation between the total length of gravel bars in the river and the total length of basal gravel deposits in the channel banks. Thus, the local basal deposits appear to be an important source of chert gravel for the Neosho River. The basal deposits are of alluvial origin and are common in the Neosho River flood plain.

Available evidence indicates that the erosional and depositional processes that are responsible for gravel-bar formation in the Neosho River generally operate intermittently in association with infrequent large flows. Thus, chert gravel bars in the river may require up to several years to recover from in-channel gravel mining unless a very large flow occurs shortly after mining. Given the importance of basal deposits as a source of gravel, John Redmond Reservoir likely has little effect on sources of gravel to the downstream Neosho River over a period of years to decades unless a very large flow occurs. Ultimately, the chert gravel in the Neosho River is essentially a finite resource as its major present-day source appears to be the finite basal deposits.

\section{Introduction}

Gravel (rock fragments ranging from 2 to $64 \mathrm{~mm}$ in size) is an important resource issue in the Neosho River Basin downstream from John Redmond Reservoir in southeastern Kansas (figs. $1 B$ and $1 C$ ). The presence and movement of gravel in a river system affects channel geometry, channel migration, channel stability, and in-stream habitat. For the Neosho madtom (Noturus placidus), a threatened and endangered species of catfish (U.S. Fish and Wildlife Service, 1991, 2004), gravel is an essential component of the in-stream habitat required for survival (U.S. Fish and Wildlife Service, 1991). The Kansas Water Office has identified the Neosho madtom as an important consideration in all issues related to water supply, water quality, and growth and development in and along the Neosho River (Kansas Water Office, 1993). Finally, gravel also is essential to the individuals who rely on extraction of the resource for their livelihood. Historically, Neosho River gravel has been used for several purposes including road and driveway construction. For these reasons, understanding the sources, transport, and deposition of gravel in the Neosho River Basin is important.

Since the completion of John Redmond Reservoir in 1964 by the U.S. Army Corps of Engineers (USCOE), questions about the gravel resource have emerged. For example, is the gravel in the Neosho River downstream from John Redmond Reservoir a finite resource? It is commonly believed that the original source of gravel to the Neosho River is the Flint Hills Upland (figs. $1 A$ and 2), which is located upstream from John Redmond Reservoir. With the construction of the dam, this original source of gravel to the downstream Neosho River has been effectively eliminated. Thus, if the Flint Hills Upland is the only source, it is possible that the gravel in the Neosho River downstream from John Redmond Reservoir eventually may be depleted by natural processes and in-channel gravel mining. A second question addresses the possibility of gravel replenishment along the Neosho River. Specifically, do tributaries or basal channel-bank deposits along the Neosho River provide substantial inputs of gravel? The answers to these questions are important for the future management of the Neosho River system, especially as related to the ability to successfully balance the needs of nature and humans with regard to the gravel resource. 


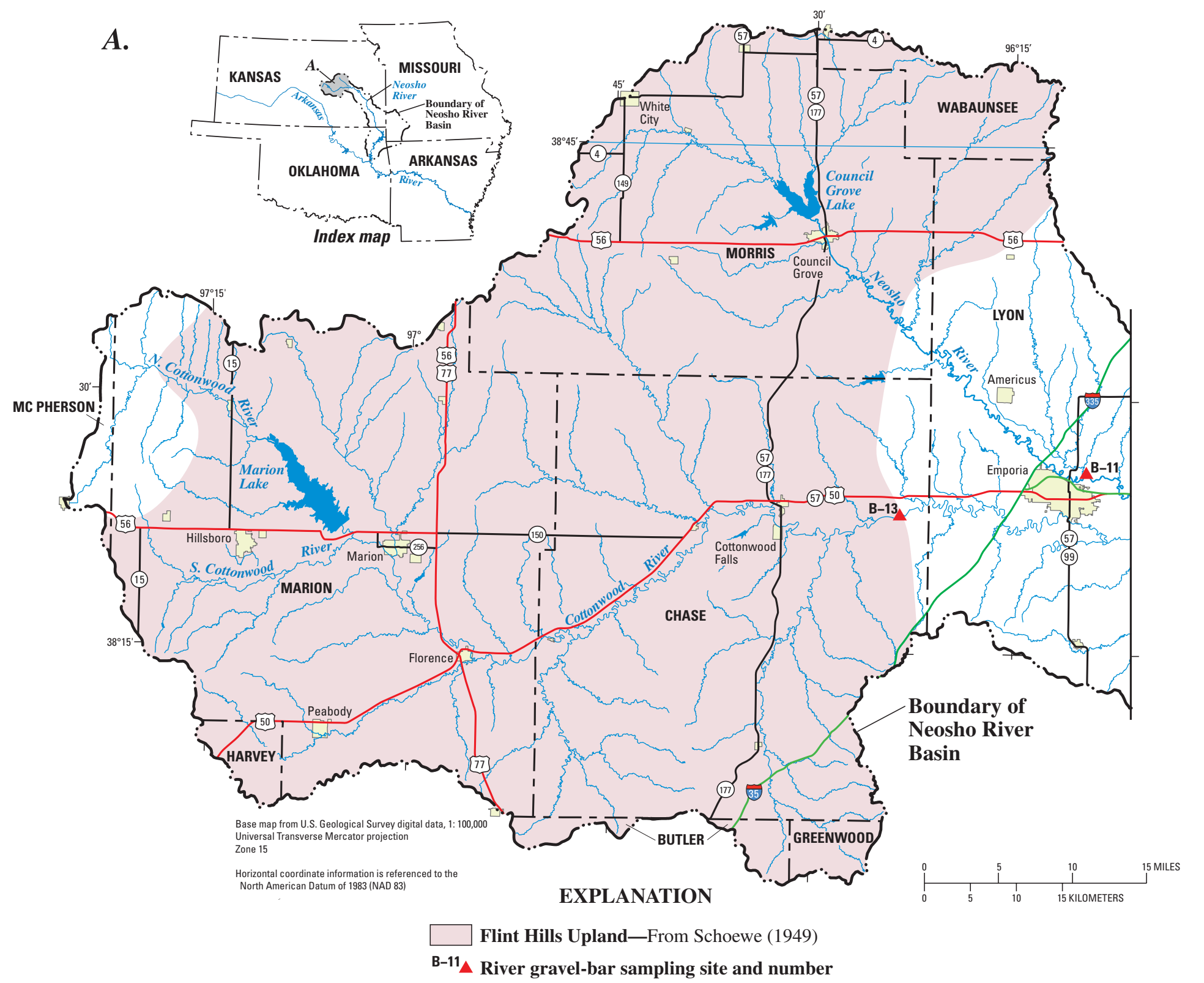

Figure 1. Location of Neosho River Basin in Kansas, John Redmond Reservoir, major tributaries, sampling sites, U.S. Geological Survey streamflow-gaging stations, inspection sites, and overflow dams. 


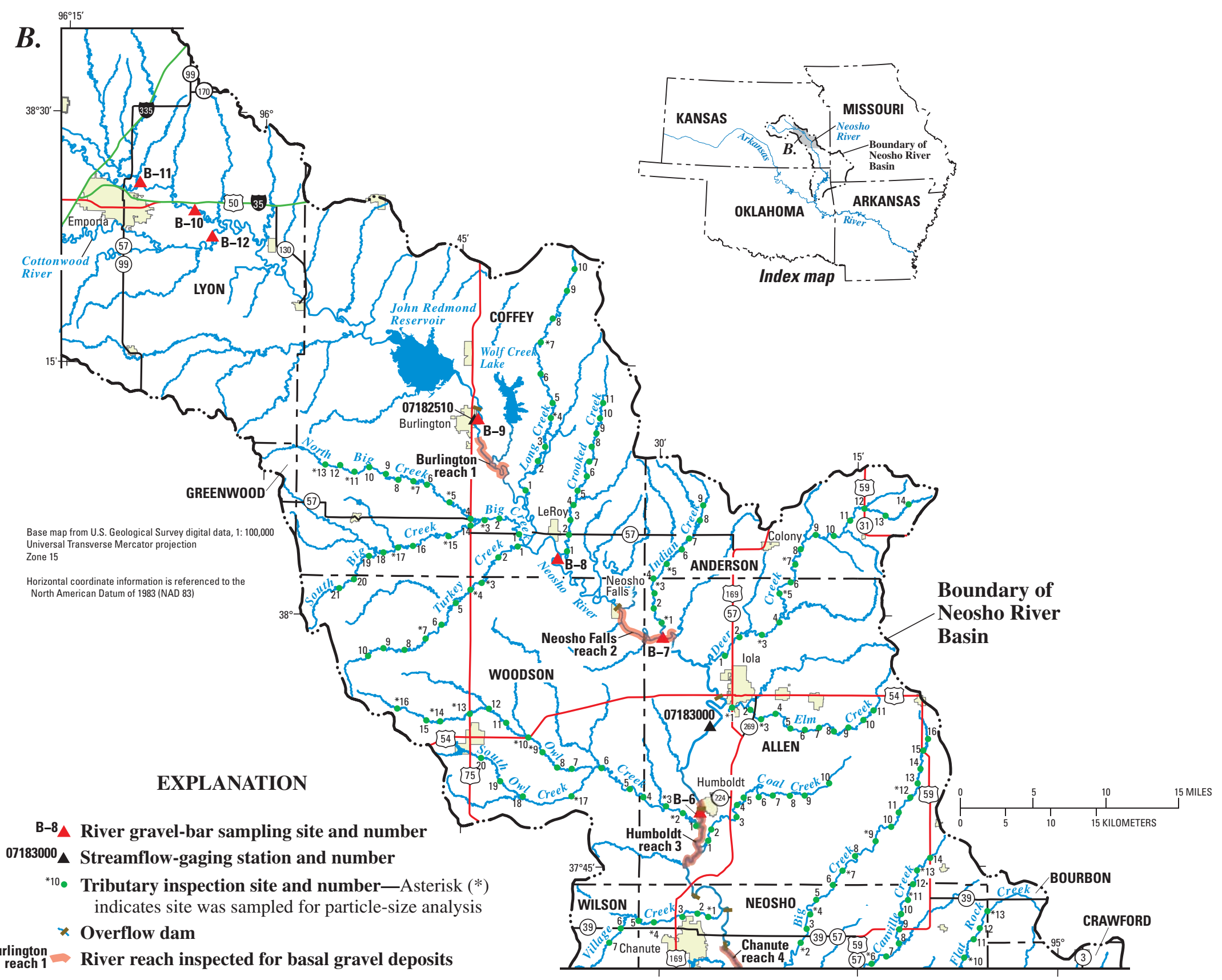

Figure 1. Location of Neosho River Basin in Kansas, John Redmond Reservoir, major tributaries, sampling sites, U.S. Geological Survey streamflow-gaging stations, inspection sites, and overflow dams.-Continued 


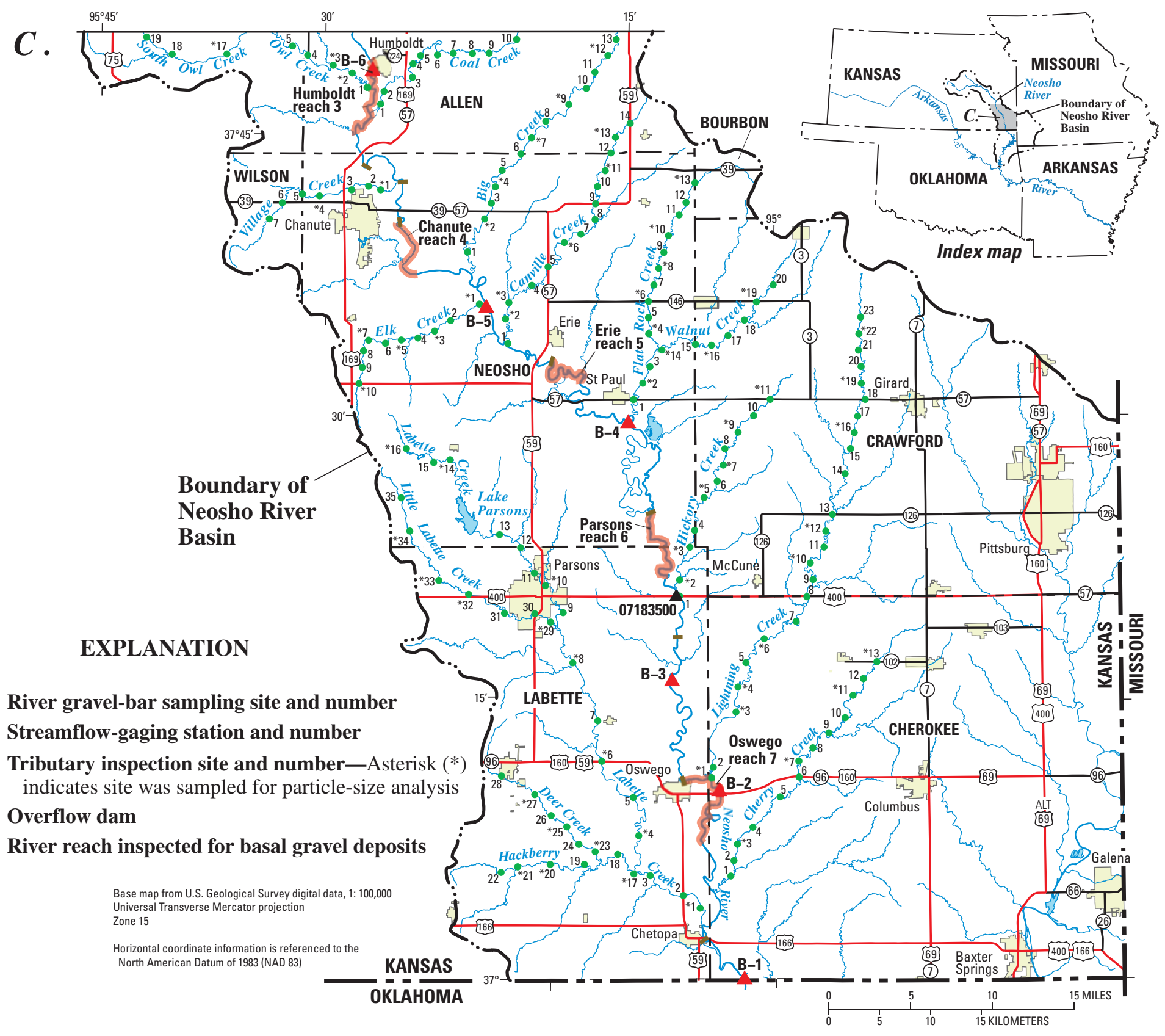

Figure 1. Location of Neosho River Basin in Kansas, John Redmond Reservoir, major tributaries, sampling sites, U.S. Geological Survey streamflow-gaging stations, inspection sites, and overflow dams.-Continued 


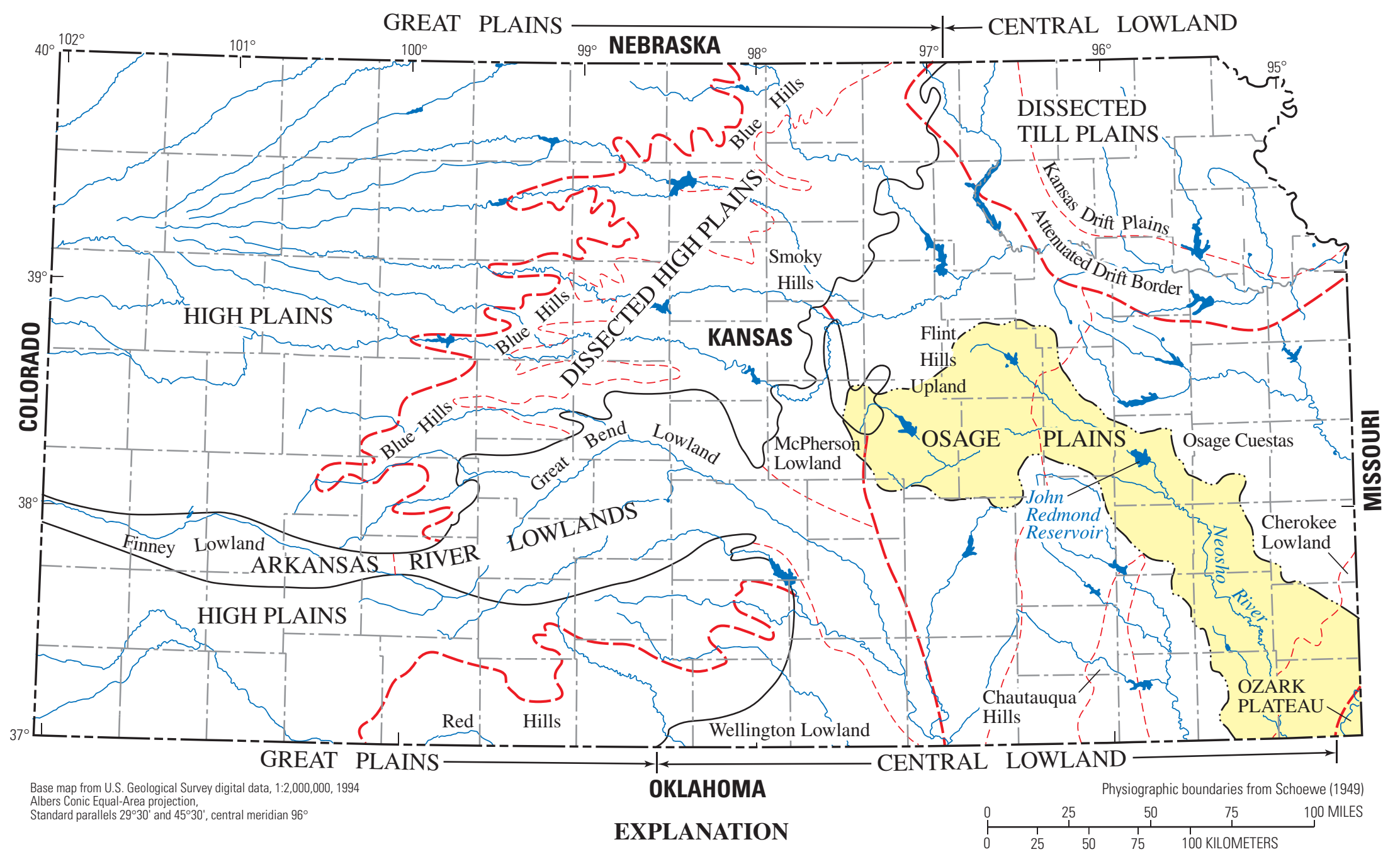

Extent of Neosho River Basin in Kansas

Boundary of physiographic province

- - - Boundary of physiographic section

-- - - Boundary of physiographic minor divisions

Figure 2. Physiography of Kansas in relation to the Neosho River Basin. 
The purpose of this report is to present the results of a 2 -year study by the U.S. Geological Survey (USGS) that was begun in 2004 to determine potential gravel sources for the Neosho River in Kansas. The study was done in cooperation with USCOE. The specific study objectives were to:

1. Characterize the longitudinal variability in composition and particle size for gravel in bar deposits located in the Neosho River both upstream and downstream from John Redmond Reservoir;

2. Determine the occurrence, composition, and particle size of gravel in bar deposits in a spatially representative sample of tributaries to the Neosho River downstream from John Redmond Reservoir;

3. Determine the spatial distribution of gravel bars along the Neosho River downstream from John Redmond Reservoir;

4. Determine the occurrence of exposed basal gravel deposits in the channel banks of the Neosho River downstream from John Redmond Reservoir; and

5. Assess the potential of the tributaries and basal gravel deposits as sources of gravel for the Neosho River downstream from John Redmond Reservoir.

The study objectives were accomplished using a combination of onsite inspection, sampling, and aerial photography. Results presented in this report will assist USCOE in future decisions regarding the management of the gravel resource. From a national perspective, the results presented in this report provide information on the important issues of sediment supply and habitat maintenance downstream from reservoirs.

\section{Description of Neosho River Basin}

The Neosho River Basin is about $12,400 \mathrm{mi}^{2}$ in size and covers parts of Kansas, Missouri, Arkansas, and Oklahoma (fig. 1). From its headwaters in central Kansas, the Neosho River flows generally southeast approximately $470 \mathrm{mi}$ to its confluence with the Arkansas River in northeastern Oklahoma. Physiographically, the majority of the basin is in the Osage Plains Section of the Central Lowland Province (Fenneman, 1946; Schoewe, 1949). Within Kansas, the upstream one-third of the basin is located mostly in the Flint Hills Upland physiographic division, whereas the downstream two-thirds of the basin is located mostly in the Osage Cuestas physiographic division (fig. 2). Topographically, the Flint Hills Upland is characterized as gently rolling. The Osage Cuestas generally consist of a series of irregular northeast-southwest trending escarpments between which are flat to gently rolling plains (Schoewe, 1949). In the Kansas part of the Neosho River Basin, bedrock is predominantly alternating limestone and shale of Permian age in the Flint Hills Upland and Pennsylvanian age downstream. The bedrock is overlain by Quaternary alluvium in the valleys of the Neosho River and its major tributaries (Kansas Geological Survey, 1964; Marcher and others, 1984). Land use in the Neosho River Basin is predominantly a mix of crop- land and grassland (Kansas Applied Remote Sensing Program, 1993).

Long-term, mean annual precipitation in the Kansas part of the Neosho River Basin ranges from about 32 in. at Hillsboro (period of record 1948-2003), in the northwestern part of the basin (fig. 1A), to about 42 in. at Columbus (period of record 1900-2003) in the southeastern part (fig. 1C) (High Plains Regional Climate Center, 2004). Most of the precipitation is received during the growing season (generally, AprilSeptember).

The main focus of the study described in this report was the 180-mi reach of the Neosho River situated between John Redmond Reservoir and the Kansas-Oklahoma State line (fig. 1). Throughout this reach, the Neosho River is characterized by a meandering channel the bed of which typically consists of some combination of bedrock, cobble, gravel, sand, and silt. The channel slope averages about $1.2 \mathrm{ft} / \mathrm{mi}$ (Carswell and Hart, 1985). Riverbank height typically varies from about 15 to $30 \mathrm{ft}$ (U.S. Army Corps of Engineers, 1972). The channel bed frequently is situated on Pennsylvanian bedrock (Williams, 1944; U.S. Army Corps of Engineers, 1965; Miller, 1969). Alluvium in the Neosho River Valley averages about $25 \mathrm{ft}$ in thickness and is typified by silt and clay with a basal layer of sand and gravel that averages about $3 \mathrm{ft}$ in thickness (Jungmann, 1966; Miller, 1969; Morton and Fader, 1972). The channelbank materials consist mostly of cohesive silt and clay (Osterkamp and Hedman, 1981). Also, the channel banks typically are covered by partial to complete mature tree cover that may enhance bank stability at some locations (Thorne, 1990; Beeson and Doyle, 1995).

The gravel in the Neosho River consists predominantly of brownish chert that typically is rounded but sometimes angular. Chert is a hard, extremely dense cryptocrystalline form of quartz (Buchanan, 1984). The chert gravel in the Neosho River originated from cherty limestone units of Permian age located in the Flint Hills Upland. From its origin in the Flint Hills Upland, the chert gravel was eroded, transported, and deposited in ancient river channels throughout eastern Kansas (O'Conner, 1953; Frye, 1955; Aber, 1997). Subsequent erosion of the landscape has left the old alluvial chert gravel deposits of Tertiary age situated on high terraces and hilltops in parts of the Neosho River Basin and elsewhere in eastern Kansas. The Olpe soil is a reliable indicator for the presence of alluvial chert gravel deposits in the uplands of eastern Kansas (Aber, 1997) (fig. 3). Historical erosion, transport, and deposition processes resulted in basal chert gravel deposits of uncertain spatial extent in the flood plain of the Neosho River. Fossil evidence in the vicinity of Emporia suggests that the basal chert deposits are late Pleistocene to Holocene in age (James Aber, Emporia State University, written commun., 2005).

Inspection of USGS 1:24,000-scale topographic quadrangles indicated that gravel extraction pits are common in parts of the Neosho River Basin both in the flood plain and in the uplands. An upland gravel extraction pit located about $4 \mathrm{mi}$ west of Colony, Kansas, is shown in figure 4. Gravel has been mined from these pits and from gravel bars within the Neosho River channel. 


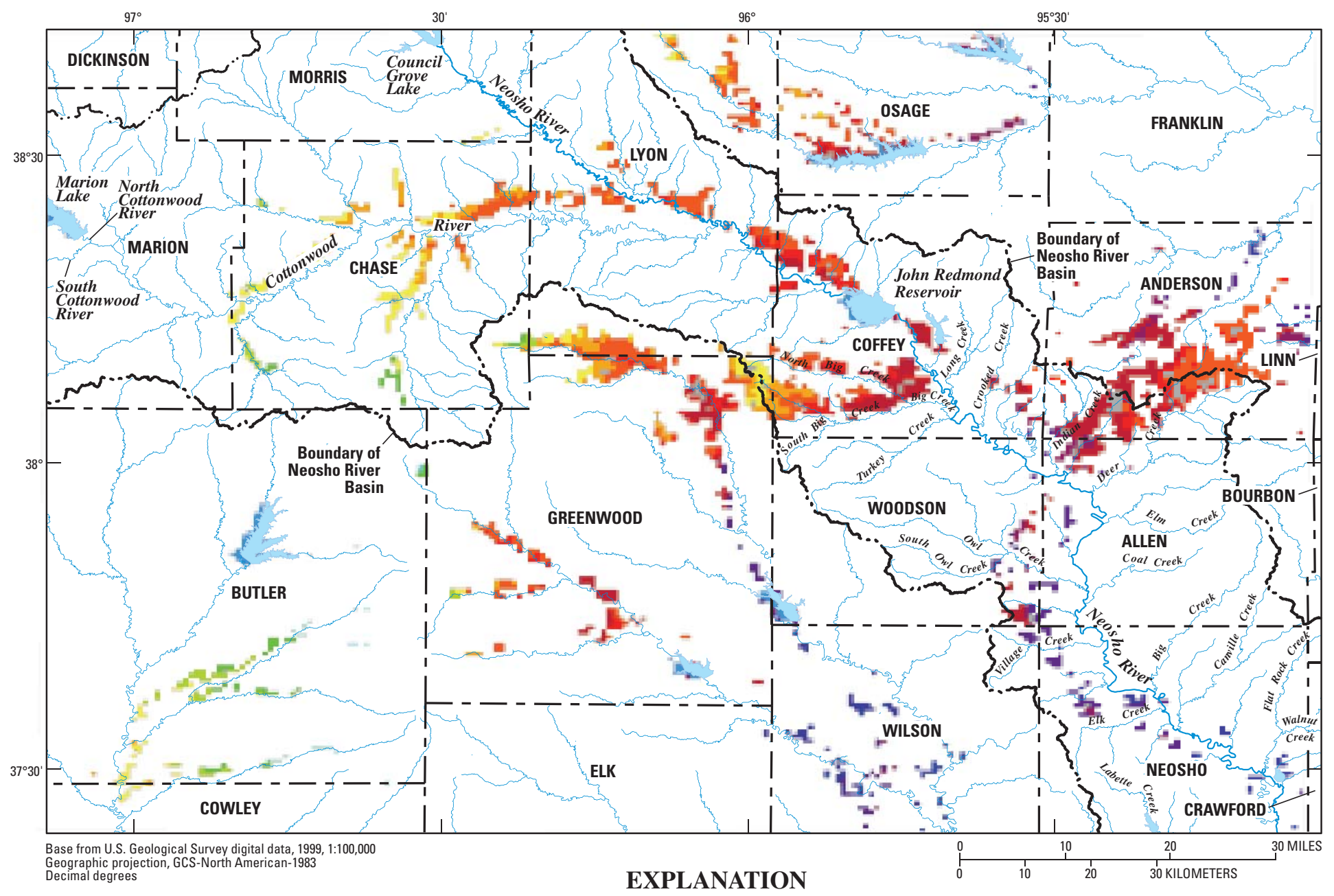

Horizontal coordinate information is referenced to the
North American Datum of 1983 (NAD 83)

Kansas chert gravel (Olpe soil)_Approximate elevation in

feet above North American Vertical Datum of 1988 (NAVD 88)

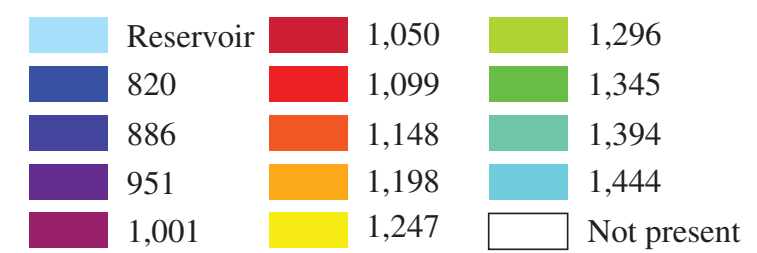

Figure 3. Approximate distribution of the Olpe soil in uplands of eastern Kansas (modified from Aber, 1997). 
(A) Upland gravel pit west of Colony, Kansas (fig. 1B)

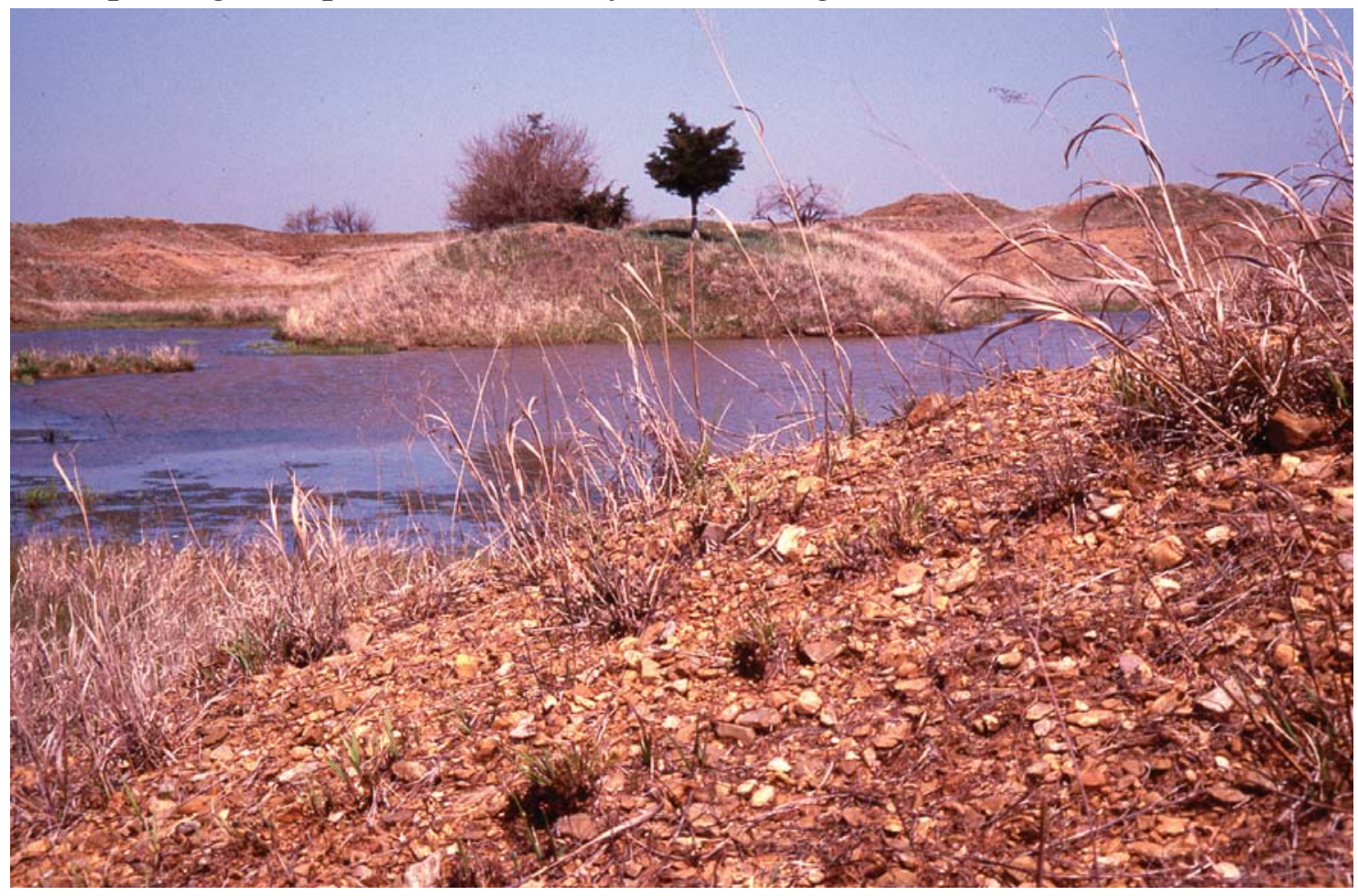

(B) Closeup of chert gravel at the site

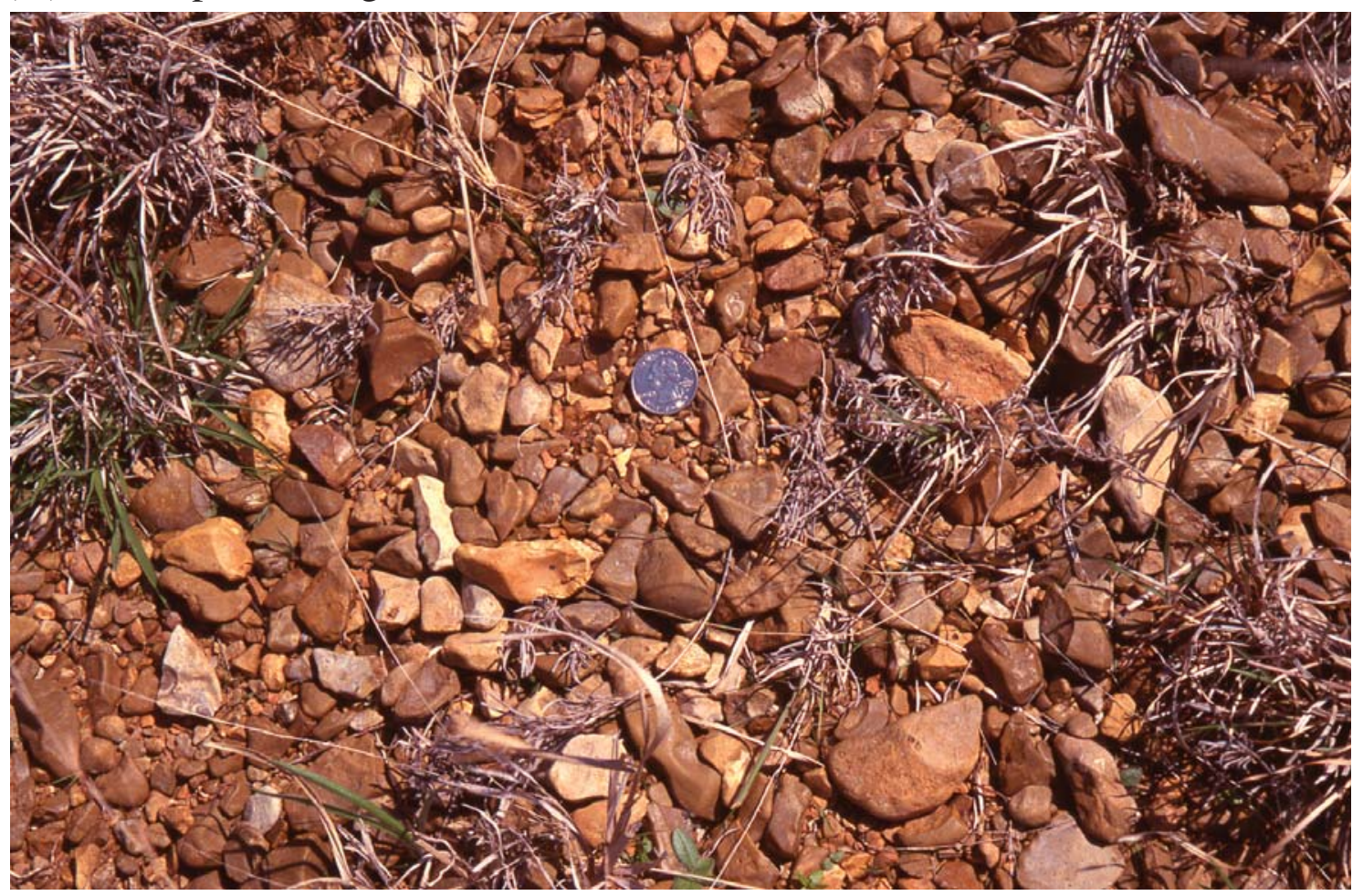

Figure 4. (A) An upland gravel pit west of Colony, Kansas, and $(B)$ a closeup of chert gravel at the site (note quarter for scale). Photographs taken on April 16, 2004. 
Southeast of Oswego, Kansas (fig. 1C), a buried log was discovered that was embedded within a basal chert gravel deposit in the bank of the Neosho River. A sample of the log was collected and sent to the Illinois State Geological Survey for analysis to determine its radiocarbon date. The age of the log was estimated to be $420 \pm 70$ years before present (2005) (Keith Hackley, Illinois State Geological Survey, written commun., 2005). Thus, the log and chert gravel at this site likely were deposited some time between 1515 and 1655 .

\section{Regulation of Flow in the Neosho River}

John Redmond Reservoir, completed by USCOE in 1964, regulates the flow of streams from $3,015 \mathrm{mi}^{2}$ in the upstream Neosho River Basin. The spillway is gate controlled, and the reservoir had a 2000 storage capacity of 574,918 acre-ft at the top of the flood pool (James Croston, U.S. Army Corps of Engineers, written commun., 2005). Changes in the streamflow regime attributed to the operation of John Redmond Reservoir have included a decrease in the magnitudes of high-flow discharges and an increase in the magnitudes of low-flow discharges (Studley, 1996). An analysis of available USGS data indicated that post-dam suspended-sediment concentrations are reduced substantially immediately downstream from the dam (Juracek, 2000). According to Juracek (2000), the operation of John Redmond Reservoir has had little effect on the stability of the downstream Neosho River channel. Several tributaries contribute unregulated flow to the Neosho River downstream from John Redmond Reservoir (fig. 1). The basin area increases by $2,861 \mathrm{mi}^{2}$ to a total of $5,876 \mathrm{mi}^{2}$ at the streamflow gage near Commerce, Oklahoma (station 07185000), which is approximately 5 mi south of the Kansas-Oklahoma State line.

Along the Neosho River downstream from John Redmond Reservoir are 12 concrete overflow dams (also known as lowhead dams) (fig. 1) that were constructed within the main-stem channel mostly in the 1930s or 1950s. Most of the overflow dams were built for water-supply purposes to serve nearby towns. The overflow dams, which extend across the full width of the river channel, create a backwater effect upstream that likely affects gravel transport and deposition. Immediately downstream, the overflow dams can cause localized channel bed and bank erosion (Juracek, 1999).

\section{Acknowledgment}

The authors gratefully acknowledge Chauncey Shepard (long-time resident of McCune, Kansas, and long-time extractor of gravel from the Neosho River) for sharing his knowledge of the Neosho River and the gravel resource, and for providing assistance in accessing the river for onsite inspections.

\section{Methods}

Several methods were used in this study. Categorically, they consisted of the following: (1) onsite inspection and sampling of bar deposits (Neosho River and tributaries), (2) onsite inspection of basal gravel deposits in channel banks along selected reaches of the Neosho River, and (3) inspection of aerial photographs for bar deposits along the Neosho River. Bar deposits were defined as accumulations of sand, gravel, or other material in the channel, along the banks, or at the mouth of a stream or river where a decrease in flow velocity causes deposition. Basal gravel deposits were defined as accumulations of gravel previously deposited by fluvial processes (that is, deposited before the stream or river migrated to its present location) that exist at the base of a channel bank and have been exposed by erosion.

\section{Onsite Inspection and Sampling of Bar Deposits}

To characterize the longitudinal variability in the particle size and composition of gravel in bar deposits in the Neosho River, a total of 11 bars were sampled in 2004. Of the 11 bars sampled, 9 were located downstream (sites B-1 through B-9) and 2 were located upstream (sites B-10 and B-11) from John Redmond Reservoir. Additionally, two bars in the Cottonwood River near Emporia (sites B-12 and B-13) were sampled (fig. 1). All bar deposits were inspected and sampled during low-flow conditions.

The assessment of gravel in the tributaries involved the inspection of 18 streams in the Neosho River Basin to provide a spatially representative sample (fig. 1, table 1 ). The tributaries were inspected during low-flow conditions in 2004 for the presence of bar deposits that contained gravel. Inspections were made at bridge or low-water crossings beginning at a location just upstream from the tributary's confluence with the Neosho River and extending upstream to the headwaters. At each bridge or low-water crossing, the channel was inspected both upstream and downstream to the first bend. At some sites, the presence of the bridge or low-water crossing may have contributed to the deposition of material (including gravel) in the stream channel. On average, each stream was inspected at about 15 sites for a total of 265 site inspections (fig. 1, table 1). For 90 tributary sites (fig. 1), a bar deposit was sampled for particle-size analysis.

To provide an indication of the amount of gravel present at each tributary inspection site, a qualitative coding scheme was used that was based on visual inspection. A site with little or no gravel in the channel bed both upstream and downstream from the bridge or low-water crossing was assigned a code of 0 . This coding included sites with no visible bar deposits as well as sites that had bar deposits composed mostly of silt and (or) sand with only minor amounts of gravel (for example, less than 10 percent). A site with some gravel upstream and (or) downstream was assigned a code of 1 . This coding included the following: sites that had one small bar deposit of predominantly gravel 
Table 1. Neosho River tributaries in Kansas inspected for gravel and the number of sites inspected for each tributary.

\begin{tabular}{lc}
\hline \multicolumn{1}{c}{ Tributary (fig. 1) } & $\begin{array}{c}\text { Number of sites } \\
\text { inspected }\end{array}$ \\
\hline Big Creek (Coffey and Woodson Counties) & 21 \\
Big Creek (Allen and Neosho Counties) & 16 \\
Canville Creek (Allen and Neosho Counties) & 14 \\
Cherry Creek (Cherokee County) & 13 \\
Coal Creek (Allen County) & 10 \\
& 11 \\
Crooked Creek (Coffey County) & 14 \\
Deer Creek (Allen and Anderson Counties) & 10 \\
Elk Creek (Neosho County) & 11 \\
Elm Creek (Allen County) & 20 \\
Flat Rock Creek (and Walnut Creek) (Crawford and Neosho Counties) & 11 \\
Hickory Creek (Crawford and Labette Counties) & 9 \\
Indian Creek (Allen and Anderson Counties) & 35 \\
Labette Creek (and Little Labette, Hackberry, and Deer Creeks) (Labette and Neosho Counties) \\
Lightning Creek (Cherokee and Crawford Counties) & 23 \\
Long Creek (Coffey County) & 10 \\
Owl Creek (Allen and Woodson Counties) & 10 \\
Turkey Creek (Coffey and Woodson Counties) & 7 \\
Village Creek (Neosho and Wilson Counties) & 20 \\
\hline
\end{tabular}

upstream and (or) downstream, sites that had one medium-sized bar deposit of predominantly gravel upstream or downstream (but not both), and sites that had one or more bar deposits upstream and (or) downstream that were composed mostly of silt and (or) sand with a moderate amount of gravel (for example, 10 to 30 percent). A site with abundant gravel both upstream and downstream was assigned a code of 2 . This coding included sites with one or more medium to large bar deposits of predominantly gravel both upstream and downstream. The decision as to whether a bar deposit was small, medium, or large was based on subjective judgment given the channel size.

Because of the diversity of conditions encountered, subjective judgment was occasionally required to assign a site to one of the three codes as defined. For example, a site with multiple medium to large gravel bars downstream and no gravel bars upstream was assigned a value of 2 . However, if the source of the gravel was a low-water crossing (that is, road gravel), then the site was assigned a value of 0 . The qualitative ranking scheme was used to characterize and compare the tributaries that were visually inspected.

\section{Particle-Size Analysis}

The particle-size distribution of the gravel in each sampled bar deposit was determined using a variant of the pebble-count technique (Wolman, 1954). This technique involved the collection of a random sample of 100 surficial particles from the bar deposit along one or more transects during low-flow conditions. The use of transects, rather than a grid system as originally employed by Wolman (1954), is an accepted method that has been shown to provide equivalent results (Church and others, 1987; Kondolf, 1997).

For each sampled bar deposit, a representative location was selected near the middle of the bar. Using a 100-ft tape measure, a transect was established perpendicular to the long axis of the bar. Starting at the water's edge, the transect was extended landward to the edge of the bar (as determined by the channel bank and (or) the presence of permanent vegetation). Along the transect, a random sample of 100 particles was collected by picking up a particle at a predetermined interval along the tape measure (typically, every foot) (fig. 5). To ensure randomness, the particle that was directly under the top of each foot marker on the tape was selected. For relatively narrow bars, the random sample was collected using two or more parallel transects offset by $1 \mathrm{ft}$. In this study, sampling was restricted to material that was gravel size or larger.

Particle size was determined by measuring the intermediate axis of each particle to the nearest millimeter (Wolman, 1954) (fig. 6). The resulting particle-size information was used to determine the median particle size and to characterize the gravel on the basis of the frequency distribution of the sampled particles as classified into various size categories (that is, from 


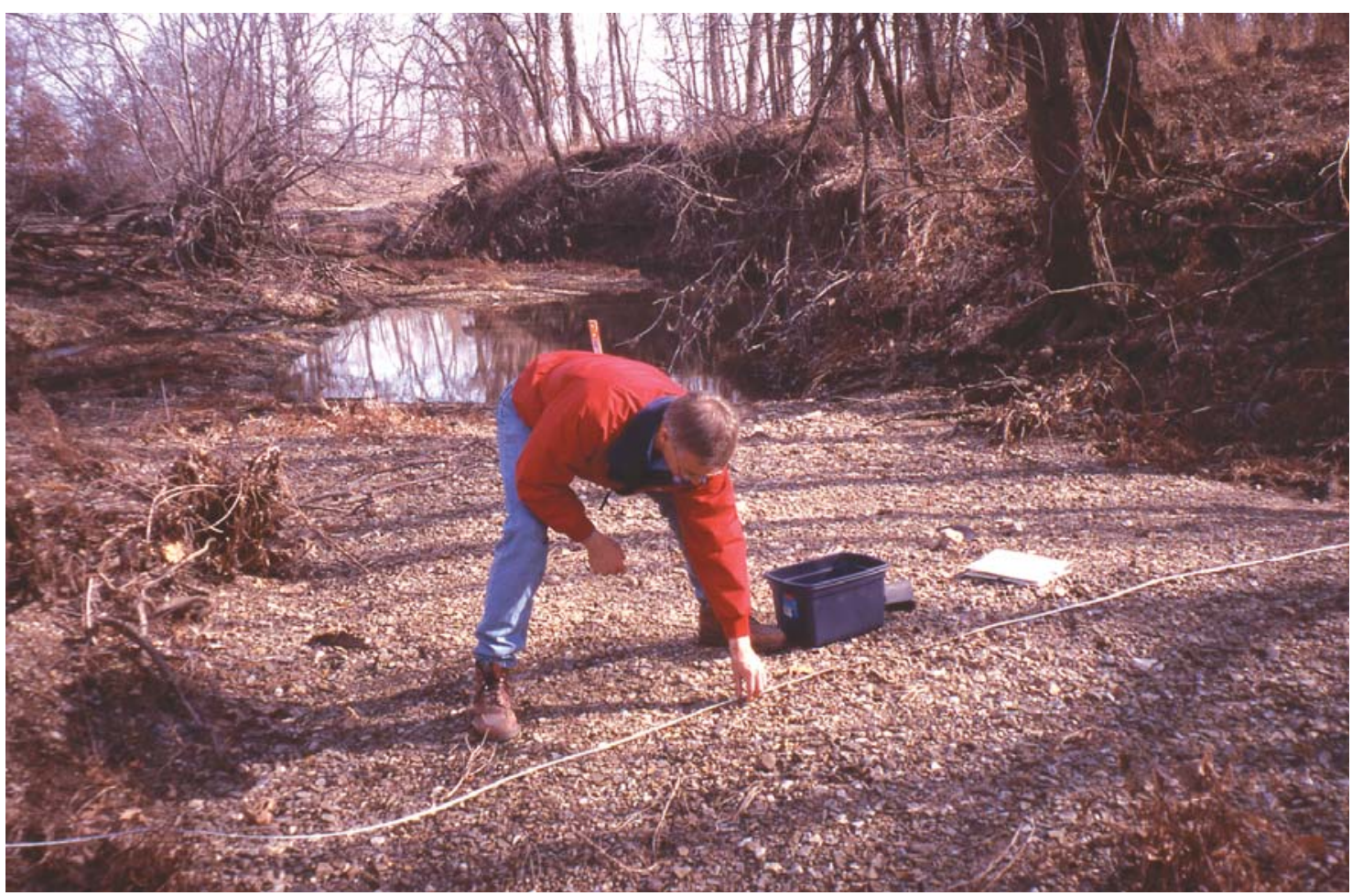

Figure 5. Collection of a random sample of gravel for subsequent particle-size analysis. Location is Indian Creek site 1 (fig. 1B). Photograph taken on February 27, 2004.

very fine gravel to small boulder). Particles were assigned to size classes according to a modified version of the Wentworth scale (Wentworth, 1922; Gordon and others, 1992) (table 2). Particles with an intermediate axis equivalent to a class break were assigned to the larger class. For example, a particle with an intermediate axis of $8 \mathrm{~mm}$ was classified as medium gravel rather than fine gravel.

\section{Composition Analysis}

The composition of the gravel in Neosho and Cottonwood River bar deposits at 13 sites was summarized as the percentage of each pebble-count sample that was chert and the percentage that was composed of other materials. Typically, the other materials reflected the composition of nearby exposed bedrock and consisted of limestone, shale, sandstone, or some combination thereof.

For tributaries of the Neosho River in Kansas, a qualitative approach was used. On the basis of results of the visual onsite inspections (specifically, the amount of chert observed at each site), each tributary was characterized as to whether or not it was a potential source of chert gravel to the Neosho River.

\section{Onsite Inspection of Basal Gravel Deposits}

The occurrence of basal gravel deposits in the banks of the Neosho River downstream from John Redmond Reservoir was assessed by the onsite inspection of seven representative river reaches. Along the Neosho River, the river reaches were selected to provide a spatially representative sample of conditions throughout the study area. Representative reaches were inspected in 2004 near the towns of Burlington, Neosho Falls, Humboldt, Chanute, Erie, Parsons, and Oswego (fig. 1). The representative reaches ranged in length from 4.5 to $7.6 \mathrm{mi}$. Combined, the reaches provide about a 24-percent sample of the Neosho River between John Redmond Reservoir and the Kansas-Oklahoma State line. Along each reach, both banks were inspected for the presence of exposed basal gravel deposits during low-flow conditions. For each deposit located, the bank was noted (that is, left or right looking in the downstream direction), and the upstream and downstream ends were documented using global positioning system (GPS) technology. These data subsequently were used to estimate the length of each deposit. Also, for each deposit, the maximum thickness above the low-flow water surface was estimated visually.

\section{Inspection of Aerial Photographs for Bar Deposits}

Inspection of the Neosho River from John Redmond Reservoir to the Kansas-Oklahoma State line was performed using 1:12,000-scale, color infrared aerial photographs to provide a longitudinal assessment of bar-deposit locations. The aerial photography was flown during low-flow, leaf-off, ice-free conditions on 2 days during December 2004. A total of $27 \mathrm{flight}$ lines were photographed by Western Air Maps, Inc., of 


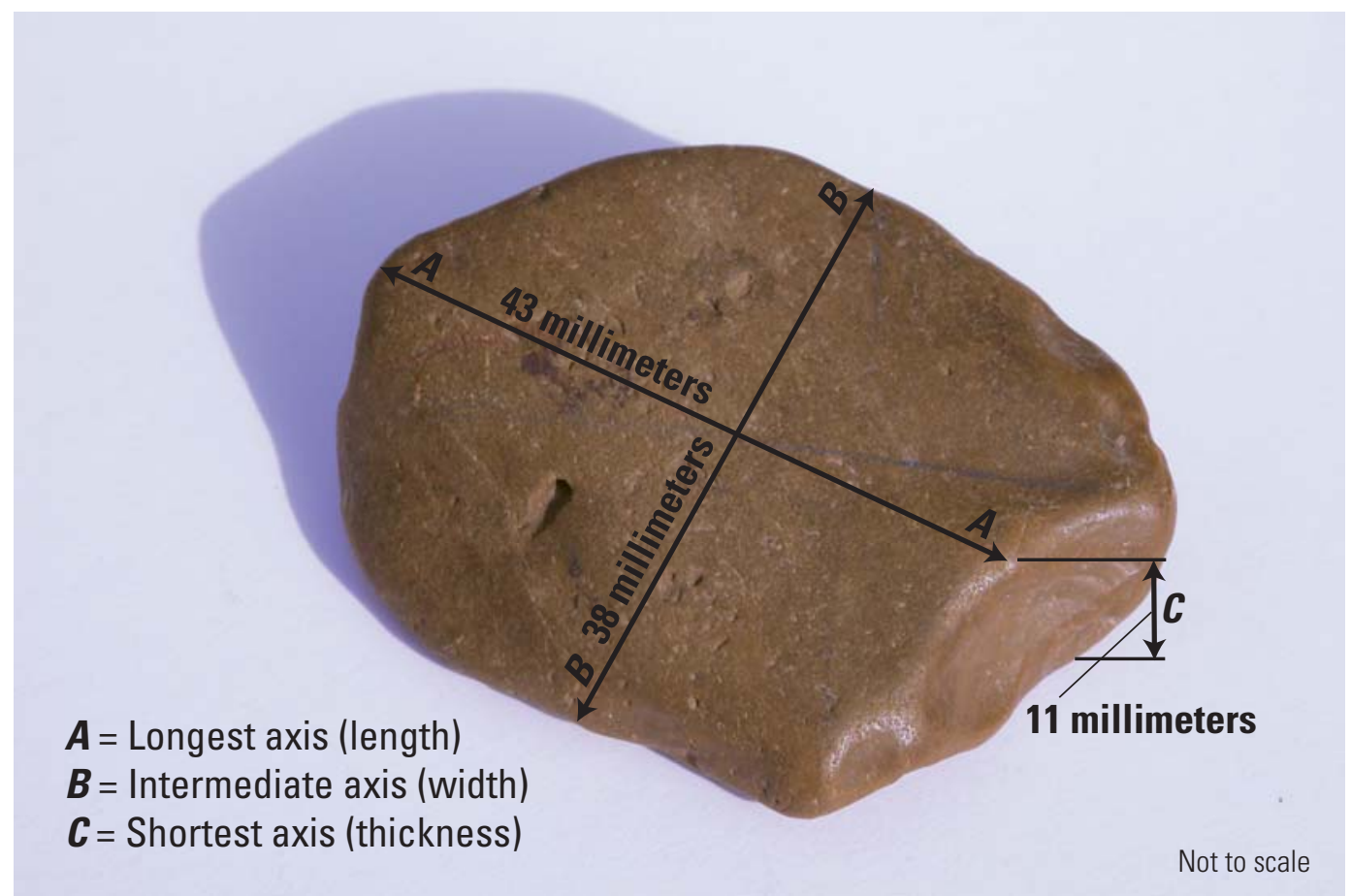

Figure 6. Longest, intermediate, and shortest axes of a gravel particle.

Overland Park, Kansas. The Neosho River from John Redmond Reservoir downstream to Humboldt, Kansas, was flown on December 3, 2004. On this day, discharges at the Neosho River streamflow-gaging stations at Burlington (station 07182510) and near Iola (station 07183000) were about 30 and $430 \mathrm{ft}^{3} / \mathrm{s}$, respectively. The Neosho River from Humboldt downstream to the Oklahoma State line was flown on December 14, 2004. On this day, discharge at the Neosho River streamflow-gaging stations near Iola and near Parsons (station 07183500) were about 220 and $650 \mathrm{ft}^{3} / \mathrm{s}$, respectively. These flow values are all less than the estimated regulated median flows of 397,581 , and $852 \mathrm{ft}^{3} / \mathrm{s}$, respectively, for streamflow gages at Burlington, near Iola, and near Parsons (Perry and others, 2004). Periods of less than median flow were chosen for best exposure of the bar deposits in the photographs. The location of the gaging stations is shown in figure 1 .

The aerial photographs were scanned to create $300 \mathrm{dpi}$ (dots per inch) color TIFF (tagged image file format) files. Using ArcGIS software (ESRI, 2004), the digital images for the representative reaches were georeferenced to remove distortions inherent in the aerial photographs and to project the images into the Universal Transverse Mercator (UTM) coordinate system. For this purpose, 1991 digital orthophotos of Allen County and 2002 digital orthophotos of Cherokee, Coffey, Labette, Neosho, and Woodson Counties (Kansas Data Access and Support Center, 2005) were used as reference maps. The digital images were examined to determine the location of apparent gravel bars. Using the digital images as a backdrop, the apparent gravel bars were digitized along the entire length of the Neosho River from John Redmond Reservoir to the KansasOklahoma State line. Only the lengths of the bars were mea- sured in this analysis. Widths were quite variable, and the heights above the water surface were not measurable.

\section{Gravel Characterization and Distribution}

In the following sections, the results of the investigation to determine the character and distribution of gravel sources in the Neosho River Basin are presented. Specifically, the results presented include a characterization of the longitudinal variability in composition and particle size for gravel in bar deposits in the Neosho and Cottonwood Rivers, a summary of the occurrence, composition, and particle size of gravel in bar deposits for a

Table 2. Particle-size classes.

[Source: Gordon and others (1992). mm, millimeters]

\begin{tabular}{lc}
\hline \multicolumn{1}{c}{ Class } & Size $^{1}(\mathrm{~mm})$ \\
\hline Small boulder & $256-512$ \\
Large cobble & $128-256$ \\
Small cobble & $64-128$ \\
Very coarse gravel & $32-64$ \\
Coarse gravel & $16-32$ \\
& \\
Medium gravel & $8-16$ \\
Fine gravel & $4-8$ \\
Very fine gravel & $2-4$ \\
\hline \multicolumn{2}{c}{ Length of the intermediate axis. }
\end{tabular}


spatially representative sample of tributaries to the Neosho River, a description of the spatial distribution of bar deposits in the Neosho River, and a description of the occurrence and maximum thickness of exposed basal gravel deposits in the channel banks of the Neosho River.

\section{Characterization of Neosho and Cottonwood River Bar Deposits}

To characterize the longitudinal variability in the composition and particle size of gravel in the Neosho River, a total of 11 bar deposits were sampled. Of the 11 bar deposits sampled, 9 were located downstream and 2 were located upstream from John Redmond Reservoir (figs. $1 B$ and $1 C$ ). Along the Neosho River, the downstream-most bar deposit sampled (site B-1) was southeast of Chetopa near the Oklahoma State line (fig. 1C), and the upstream-most bar deposit sampled (site B-11) was near Emporia (fig. $1 B$ ). Also, two bar deposits (sites B-12 and B-13) in the Cottonwood River near Emporia were sampled (figs. $1 A$ and $1 B$ ). Aerial and ground photographs of the Neosho River bar deposits sampled at sites B-1 (about 3 mi southeast of Chetopa) and B-8 (about 2 mi south of LeRoy) are shown in figures 7 and 8.

Compositionally, gravel in the Neosho River bar deposits consisted mostly of chert that was typically brownish in color and rounded. The dominance of chert was very consistent among the bar deposits and accounted for an average of about 85 to 95 percent of the gravel in each sample (fig. 9, table 3). The remaining 5 to 15 percent typically consisted of limestone or shale derived from local outcrops. The composition of the gravel in the two bar deposits sampled in the Cottonwood River was not consistent. At site B-12, located near the confluence with the Neosho River (fig. 1B), gravel in the bar deposit had a chert content of 75 to 85 percent and was compositionally similar to the Neosho River bar deposits. However, for the gravel in the bar deposit upstream at site B-13 (fig. 1A), the chert content was only 10 to 20 percent (table 3 ).

The dominance of chert in the Neosho River bar deposits likely is attributable, in large part, to its hardness as compared to the limestone and (or) shale that typically account for the small remaining fraction of the gravel in the deposits. The degree of hardness, defined as the relative ease or difficulty with which a mineral can be scratched, traditionally is assigned using the Mohs hardness scale. In this scale, hardness ranges from a value of 1 (softest) to 10 (hardest) (Judson and Kauffman, 1990). Using the Mohs scale, chert (composed mostly of quartz) has a hardness of 7 , and limestone (composed mostly of calcite) has a hardness of 3 (Buchanan, 1984). Thus, when subjected to erosional and transport processes, chert is much more durable in the environment. Because the Mohs hardness scale is on a logarithmic scale of microhardness (Hodge and McKay, 1934), the chert takes much longer to weather away under similar conditions than the softer local bedrock limestone. This helps to explain the persistence of ancient riverine cherty gravel deposits located on hilltops above the present-day Neosho
River. Visual differentiation between chert samples obtained from the hilltop locations and those obtained from nearby Neosho River bar deposits was virtually impossible.

The gravel in the Neosho River bar deposits also was generally consistent in terms of particle size. The gravel consisted predominantly of material that is classified as either medium or coarse gravel (that is, with an intermediate axis of 8 to $31 \mathrm{~mm}$ in length). Combined, medium and coarse gravel typically accounted for about 70 to 85 percent of each sample. Median particle sizes for the samples ranged from 11 to $22 \mathrm{~mm}$, although most of the samples had a median particle size in the range of 13 to $15 \mathrm{~mm}$ (table 3). For the Cottonwood River, gravel in the bar deposit at site B-12 had a particle-size distribution that was similar to the Neosho River bar deposits. However, gravel in the bar deposit at site B-13 had a relatively large content of fine gravel, which likely is indicative of the difference in the composition of this deposit (that is, more limestone) (table 3).

\section{Characterization of Tributary Bar Deposits}

To determine the occurrence, composition, and particle size of gravel in bar deposits for a spatially representative sample of tributaries to the Neosho River, 18 streams were inspected and sampled (fig. 1, table 1). Typically, the tributaries were characterized by considerable site-to-site variability as to the presence of gravel, which often was associated with local bedrock outcrops. For Coal and Crooked Creeks, little or no gravel was observed at all of the inspection sites. Similarly, little or no gravel was observed at the majority of the inspection sites for Cherry, Long, and Turkey Creeks. For the remaining tributaries, at least one-half of the inspection sites had either some or abundant gravel (table 4).

Compositionally, gravel in the bar deposits exhibited considerable variability both within and among the tributaries. Overall, the gravel, when present, consisted of some combination of chert, limestone, sandstone, and shale. For 15 of the 18 streams inspected, little or no chert was observed at most or all of the inspection sites. The 15 streams were Big Creek (Neosho and Allen Counties), Canville Creek, Cherry Creek, Coal Creek, Crooked Creek, Deer Creek, Elk Creek, Elm Creek, Flat Rock Creek, Hickory Creek, Labette Creek, Lightning Creek, Long Creek, Owl Creek, and Turkey Creek. The absence of chert in Deer Creek indicates that the Olpe soil, which is widespread in upstream parts of the basin (fig. 3 ), is not a viable source of chert to the stream. This finding is consistent with Byerley (1995) who concluded that the upland chert deposits (represented by the Olpe soil) are not a viable source of chert replenishment for the Neosho River due to the generally high and remote topographic position of the deposits with respect to the river and most major tributaries. Of the 15 streams, 5 (Cherry Creek, Elk Creek, Hickory Creek, Lightning Creek, and Owl Creek) included one downstream site on the Neosho River flood plain at which abundant chert was observed. 


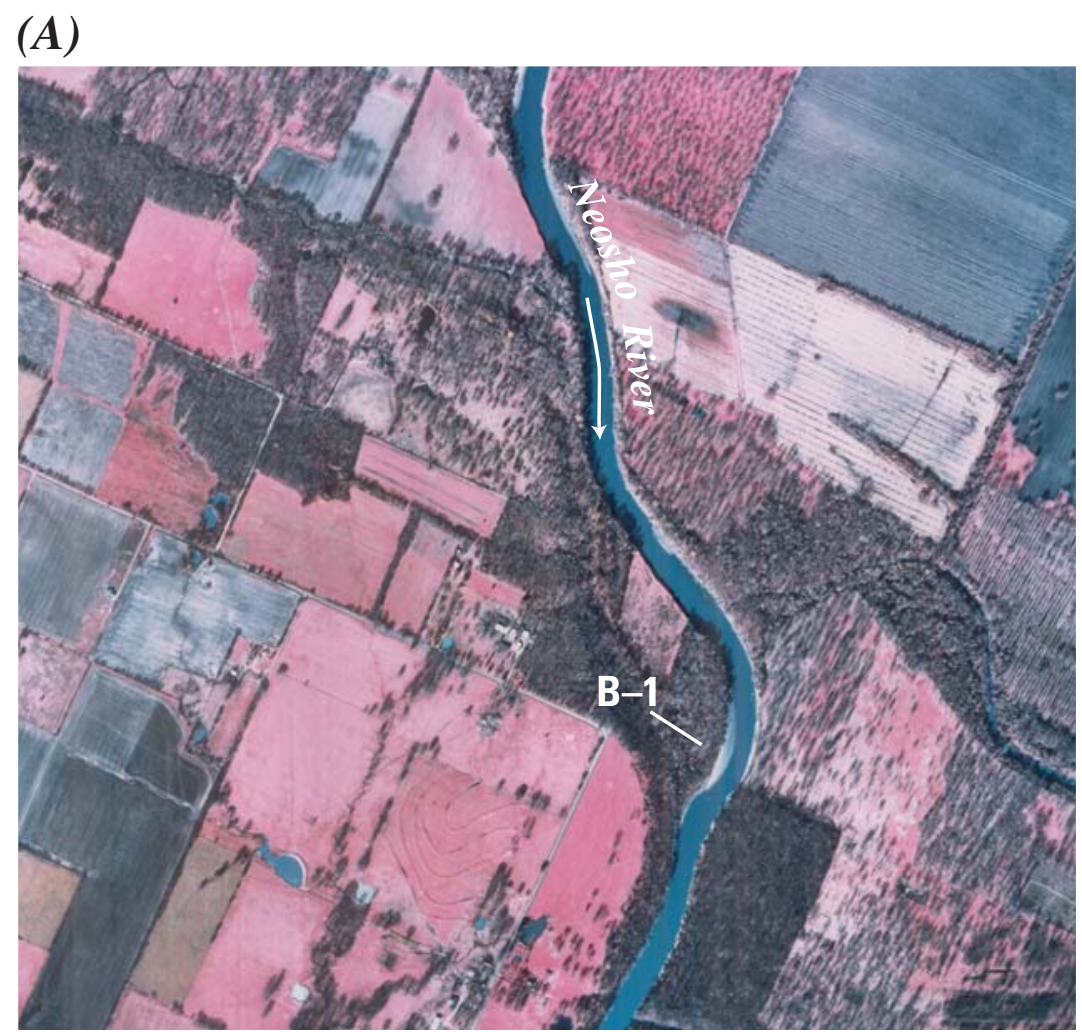

(B)

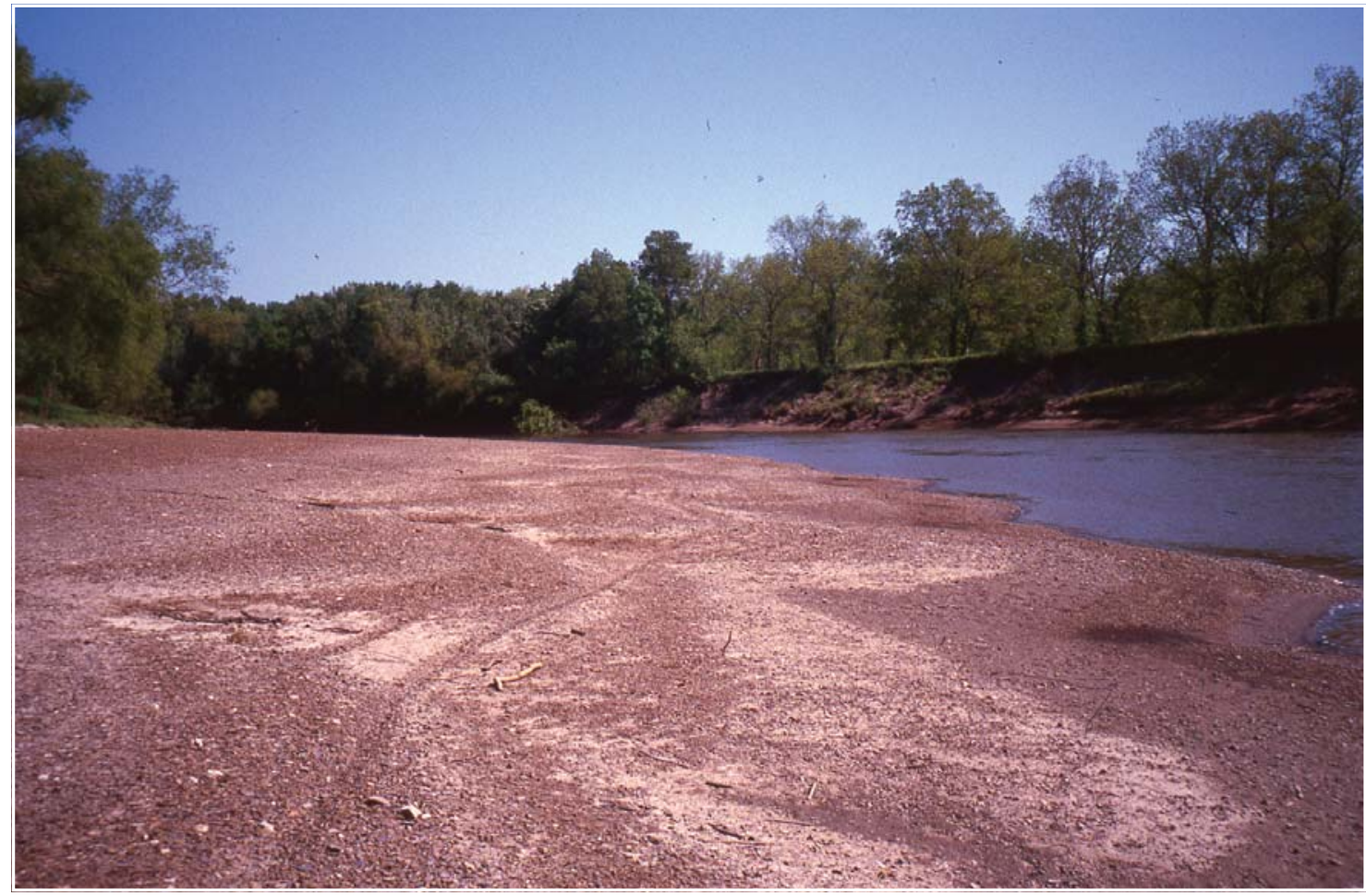

Figure 7. Gravel bar sampling site B-1 in Neosho River southeast of Chetopa, Kansas. Shown are the $(A)$ aerial view of the gravel bar and the $(B)$ ground view of the gravel bar looking upstream. Arrow on aerial photograph shows direction of streamflow. Location of sampling site shown in figure $1 C$. Aerial photograph taken on December 14, 2004, by Western Air Maps, Inc. Ground photograph taken May 7, 2004. 


\section{(A)}

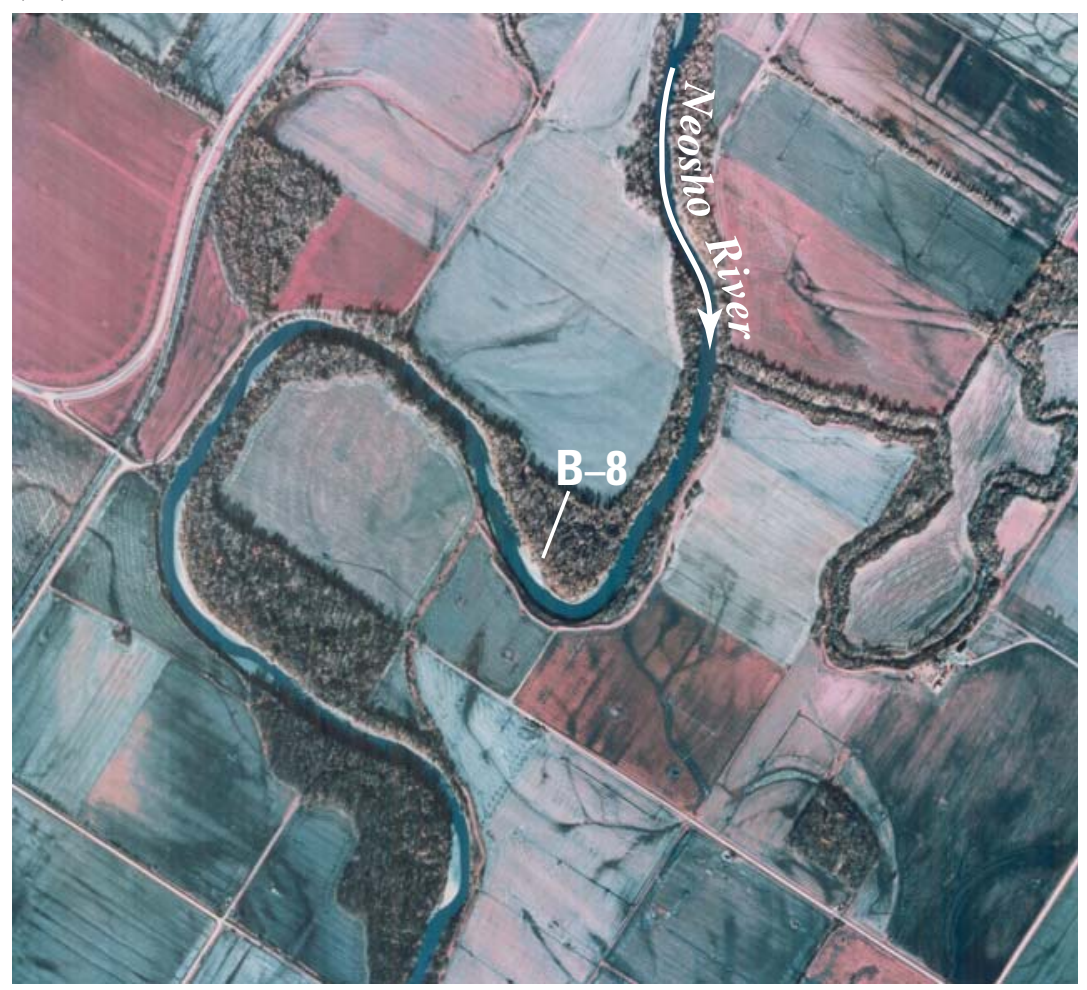

(B)

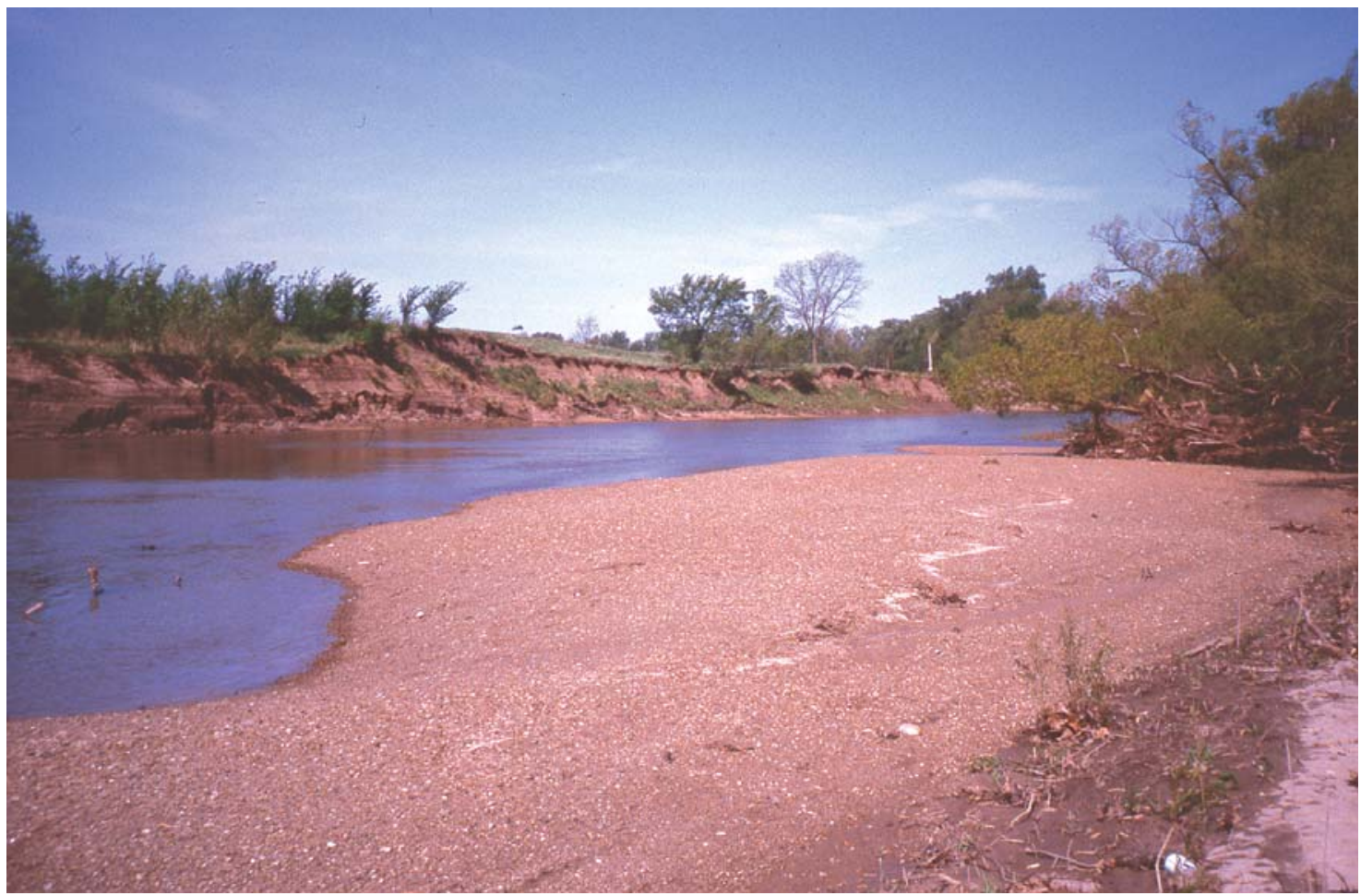

Figure 8. Gravel bar sampling site B-8 in Neosho River south of LeRoy, Kansas. Shown are the (A) aerial view of the gravel bar and the $(B)$ ground view of the gravel bar looking downstream. Arrow on aerial photograph shows direction of streamflow. Location of sampling site shown in figure $1 B$. Aerial photograph taken on December 3, 2004, by Western Air Maps, Inc. Ground photograph taken April 28, 2004. 
Table 3. Chert content and particle-size data for gravel in bar deposits sampled in the Neosho and Cottonwood Rivers, Kansas, 2004.

[mm, millimeters; --, not present in sample]

\begin{tabular}{|c|c|c|c|c|c|c|c|c|c|}
\hline \multirow[b]{2}{*}{$\begin{array}{l}\text { River } \\
\text { sampling } \\
\text { site } \\
\text { number } \\
\text { (fig. 1) }\end{array}$} & \multirow[b]{2}{*}{$\begin{array}{c}\text { Chert } \\
\text { content } \\
\text { (percent) }\end{array}$} & \multicolumn{7}{|c|}{ Number of surficial particles in each particle-size class ${ }^{1}$} & \multirow[b]{2}{*}{$\begin{array}{l}\text { Median } \\
\text { particle } \\
\text { size }(\mathrm{mm})\end{array}$} \\
\hline & & $\begin{array}{l}\text { Large } \\
\text { cobble } \\
\text { (128 to } \\
256 \mathrm{~mm} \text { ) }\end{array}$ & $\begin{array}{c}\text { Small } \\
\text { cobble } \\
\text { (64 to } 128 \mathrm{~mm} \text { ) }\end{array}$ & $\begin{array}{c}\text { Very } \\
\text { coarse } \\
\text { gravel } \\
\text { (32 to } 64 \mathrm{~mm})\end{array}$ & $\begin{array}{c}\text { Coarse } \\
\text { gravel } \\
\text { (16 to } 32 \mathrm{~mm} \text { ) }\end{array}$ & $\begin{array}{c}\text { Medium } \\
\text { gravel } \\
\text { (8 to } 16 \mathrm{~mm} \text { ) }\end{array}$ & $\begin{array}{c}\text { Fine } \\
\text { gravel } \\
(4 \text { to } 8 \mathrm{~mm})\end{array}$ & $\begin{array}{c}\text { Very } \\
\text { fine } \\
\text { gravel } \\
\text { (2 to } 4 \mathrm{~mm})\end{array}$ & \\
\hline \multicolumn{10}{|c|}{ Neosho River } \\
\hline B-1 & $85-95$ & -- & -- & 4 & 35 & 44 & 16 & 1 & 13 \\
\hline B-2 & $85-95$ & -- & -- & 4 & 41 & 41 & 13 & 1 & 14 \\
\hline B-3 & $70-80$ & -- & -- & 3 & 32 & 36 & 19 & 10 & 11 \\
\hline B-4 & $85-95$ & -- & 1 & 1 & 33 & 49 & 14 & 2 & 14 \\
\hline B-5 & $85-95$ & -- & -- & 3 & 45 & 38 & 13 & 1 & 14 \\
\hline B-6 & $80-90$ & -- & 1 & 12 & 39 & 34 & 13 & 1 & 16 \\
\hline $\mathrm{B}-7$ & $90-100$ & -- & 1 & 18 & 55 & 20 & 4 & 2 & 22 \\
\hline B-8 & $80-90$ & -- & -- & 3 & 34 & 45 & 17 & 1 & 13 \\
\hline B-9 & $85-95$ & -- & -- & 4 & 46 & 29 & 18 & 3 & 15 \\
\hline B-10 & $80-90$ & -- & -- & 3 & 47 & 40 & 10 & -- & 15 \\
\hline B-11 & $90-100$ & -- & -- & 8 & 54 & 34 & 4 & -- & 17 \\
\hline \multicolumn{10}{|c|}{ Cottonwood River } \\
\hline B-12 & $75-85$ & -- & -- & 11 & 51 & 25 & 12 & 1 & 19 \\
\hline B-13 & $10-20$ & 1 & 3 & 9 & 20 & 34 & 28 & 5 & 12 \\
\hline
\end{tabular}

${ }^{1}$ Particle-size classes from Gordon and others (1992). Particles with an intermediate axis length equivalent to the size break between two classes were assigned to the larger class.

Substantial chert was observed at several inspection sites for Big Creek (Coffey and Woodson Counties), Indian Creek, and Village Creek (fig. 3). For Indian Creek, the downstreammost six sites contained abundant chert. For Village Creek, the downstream-most site on the Neosho River flood plain contained abundant chert. Little chert was observed at the downstream-most two sites for Big Creek. The Olpe soil is widespread in the Big Creek Basin but less common in the Indian Creek and Village Creek Basins (fig. 3). The viability of the Olpe soil as a source of chert to the three streams is uncertain. At some sites along all three streams, basal cherty gravel deposits were observed in the channel banks in the vicinity of inchannel cherty gravel bars. This observation indicated that basal deposits likely are an important source of chert to these streams.

Site-to-site variability also typified the tributary bar deposits in terms of the particle-size distribution of the gravel. Information on the particle-size distribution for 90 tributary inspection sites at which a bar deposit was sampled is provided in table 6 in the "Supplemental Information" section at the back of this report. At individual inspection sites the gravel typically consisted of large percentages of medium and (or) coarse gravel (that is, with respective intermediate axis lengths of 8 to 15 and 16 to $31 \mathrm{~mm}$ ). Also, the gravel at several inspection sites included a large percentage of fine (intermediate axis length of
4 to $7 \mathrm{~mm}$ ) and (or) very coarse (intermediate axis length of 32 to $63 \mathrm{~mm}$ ) gravel. The gravel at a few inspection sites included a substantial percentage of very fine gravel (intermediate axis length of 2 or $3 \mathrm{~mm}$ ) or small cobbles (intermediate axis length of 64 to $127 \mathrm{~mm}$ ). Median particle sizes at the inspection sites ranged from 5 to $53 \mathrm{~mm}$ (table 6).

\section{Distribution of Bar Deposits in the Neosho River}

The entire length of the Neosho River from John Redmond Reservoir to the Kansas-Oklahoma State line was examined for the presence and length of bar deposits using 1:12,000-scale, color infrared aerial photographs taken in December 2004. These aerial photographs were visually compared with other aerial photographs taken in 1991 and 1992 (TerraServer, 2005). The level of flow in the Neosho River affected the amount of apparent bar deposits that was visible. Low flows in 1991 of less than $30 \mathrm{ft}^{3} / \mathrm{s}$ from John Redmond Reservoir to Chanute (fig. 1B) exposed a considerable amount of the channel bed, whereas high flows in 1992 obscured nearly all of the deposits from Chanute downstream to the Oklahoma State line (fig. 1C). In spot checks of the Neosho River upstream from Chanute, the apparent bar deposits were quite static in terms of location and extent 


\section{(A) Sampling site $\mathrm{B}-1$}

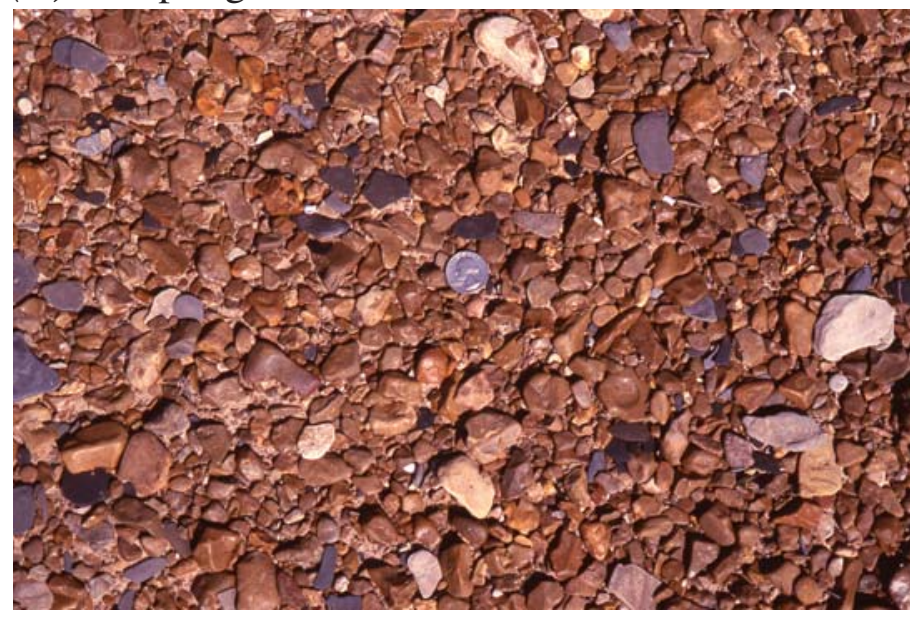

(B) Sampling site B-8

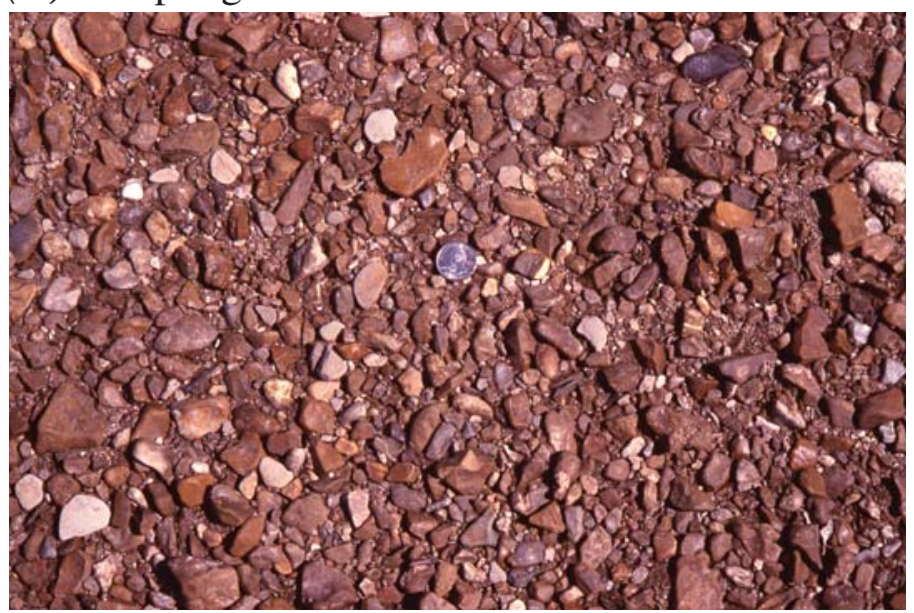

(C) Sampling site B-10

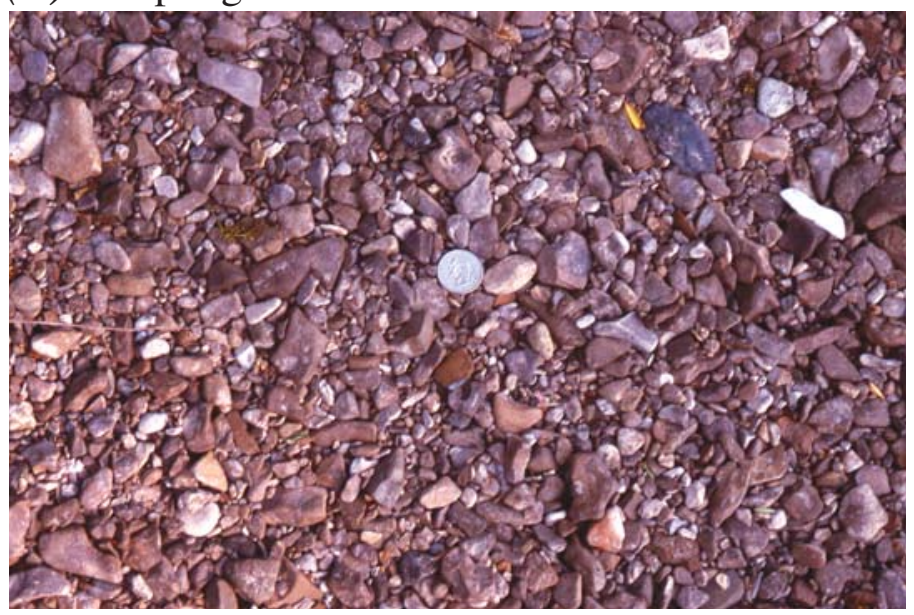

Figure 9. Closeup of chert in gravel bars sampled at $(A)$ site $B-1$, $(B)$ site $B-8$, and $(C)$ site $B-10$ in the Neosho River (note quarter for scale). The difference in color at site $B-10$ was caused by shaded conditions at the sampling site. Location of sampling sites shown in figure 1. as determined by a comparison of 1991 and 2004 aerial photography.

The identification of gravel bars from aerial photographs was a somewhat subjective process because there are several types of deposits along the Neosho River. Mud bars, which consist of fine sediment, have shapes similar to gravel bars but tend to appear darker in the aerial photographs. Also, the mud bars are at times associated with bank sloughing and can occur on the outside of a channel bend, which is usually an area of erosion (that is, a cutbank). The characteristic cherty gravel bars in the Neosho River appear as tan to gray deposits along the inside of channel bends (that is, point bars), at locations where the channel widens, and near riffles in the channel. Other gravel and cobble bars are associated with localized outcrops of native limestone. These bar deposits tend to be lighter in color compared to the cherty gravel when viewed on the aerial photographs. There also are localized bedrock exposures on the channel bed that, like the gravel and cobble bars, tend to be lighter in color.

Cobble bars and bedrock exposures are distinguishable from gravel bars because of their more irregular shape. Gravel bars are characterized by a smooth shape with a point at the downstream termination, whereas cobble bars and bedrock exposures have a more irregular appearance that lacks such a point. Moreover, gravel bars are typified by a parallel orientation to the direction of flow within the channel, whereas cobble bars form as a series of deposits perpendicular to the direction of flow (fig. 10). The difference in shape and orientation between the gravel and cobble bars is caused, in part, by the difference in the size of the materials in relation to the ability of flowing water to transport and deposit the materials. Other problems with identifying apparent gravel bars along the channel included the long winter shadows cast by the steep channel banks and by trees.

For the 180-mi reach of the Neosho River situated between John Redmond Reservoir and the Kansas-Oklahoma State line, the total length of apparent gravel bars was approximately $44 \mathrm{mi}$. This total includes bars on both sides of the channel. The ratio of apparent gravel-bar length to channel length is approximately 1:4. However, from the aerial photographs it was apparent that some reaches of the Neosho River had a higher ratio of gravel-bar to channel length, whereas others had a much lower ratio.

A comparison of the 2004 aerial photographs with USGS 7.5-minute topographic quadrangle maps (with publication dates ranging from 1966 to 1978) indicated that the Neosho River has migrated substantially at some locations. Examples include the migration of the river channel around an overflow dam (northeast of Parsons, fig. 1C) and the cutoff of a large channel meander (southeast of Oswego, fig. 1C). A detailed assessment of channel migration was beyond the scope of this study. The rate of channel migration is important because it may be used to provide an indication of the amount of gravel being supplied to the Neosho River at locations where basal gravel deposits are being eroded. 
Table 4. Neosho River tributaries in Kansas inspected for gravel, number of sites inspected for each tributary, and occurrence of gravel, 2004.

\begin{tabular}{|c|c|c|c|c|c|}
\hline \multirow[b]{2}{*}{ Tributary (fig. 1) } & \multirow[b]{2}{*}{$\begin{array}{l}\text { Number of } \\
\text { sites } \\
\text { inspected }\end{array}$} & \multicolumn{4}{|c|}{ Occurrence of gravel } \\
\hline & & $\begin{array}{l}\text { Number of sites } \\
\text { with little or no } \\
\text { gravel } \\
\text { (code=0) }\end{array}$ & $\begin{array}{l}\text { Number of sites } \\
\text { with some gravel } \\
\text { (code }=1 \text { ) }\end{array}$ & $\begin{array}{c}\text { Number of sites } \\
\text { with abundant } \\
\text { gravel } \\
\text { (code=2) }\end{array}$ & $\begin{array}{l}\text { Mean } \\
\text { occurrence } \\
\text { code }^{1}\end{array}$ \\
\hline $\begin{array}{l}\text { Big Creek (Coffey and Woodson } \\
\text { Counties) }\end{array}$ & 21 & 6 & 6 & 9 & 1.1 \\
\hline Big Creek (Allen and Neosho Counties) & 16 & 8 & 4 & 4 & .8 \\
\hline $\begin{array}{l}\text { Canville Creek (Allen and Neosho } \\
\text { Counties) }\end{array}$ & 14 & 2 & 5 & 7 & 1.4 \\
\hline Cherry Creek (Cherokee County) & 13 & 8 & 4 & 1 & .5 \\
\hline Coal Creek (Allen County) & 10 & 10 & 0 & 0 & 0 \\
\hline Crooked Creek (Coffey County) & 11 & 11 & 0 & 0 & 0 \\
\hline $\begin{array}{l}\text { Deer Creek (Allen and Anderson } \\
\text { Counties) }\end{array}$ & 14 & 7 & 5 & 2 & .6 \\
\hline Elk Creek (Neosho County) & 10 & 0 & 4 & 6 & 1.6 \\
\hline Elm Creek (Allen County) & 11 & 4 & 4 & 3 & .9 \\
\hline $\begin{array}{l}\text { Flat Rock Creek (and Walnut Creek) } \\
\text { (Crawford and Neosho Counties) }\end{array}$ & 20 & 2 & 9 & 9 & 1.4 \\
\hline $\begin{array}{l}\text { Hickory Creek (Crawford and Labette } \\
\text { Counties) }\end{array}$ & 11 & 1 & 4 & 6 & 1.5 \\
\hline $\begin{array}{l}\text { Indian Creek (Allen and Anderson } \\
\text { Counties) }\end{array}$ & 9 & 0 & 3 & 6 & 1.7 \\
\hline $\begin{array}{l}\text { Labette Creek (and Little Labette, } \\
\text { Hackberry, and Deer Creeks) (Labette } \\
\text { and Neosho Counties) }\end{array}$ & 35 & 7 & 13 & 15 & 1.2 \\
\hline $\begin{array}{l}\text { Lightning Creek (Cherokee and } \\
\text { Crawford Counties) }\end{array}$ & 23 & 8 & 12 & 3 & .8 \\
\hline Long Creek (Coffey County) & 10 & 6 & 3 & 1 & .5 \\
\hline $\begin{array}{l}\text { Owl Creek (Allen and Woodson } \\
\text { Counties) }\end{array}$ & 20 & 9 & 10 & 1 & .6 \\
\hline $\begin{array}{l}\text { Turkey Creek (Coffey and Woodson } \\
\text { Counties) }\end{array}$ & 10 & 7 & 1 & 2 & .5 \\
\hline $\begin{array}{l}\text { Village Creek (Neosho and Wilson } \\
\text { Counties) }\end{array}$ & 7 & 3 & 1 & 3 & 1.0 \\
\hline
\end{tabular}

${ }^{1}$ Mean computed as the sum of the assigned site codes divided by the total number of sites inspected for each tributary.

\section{Basal Gravel Deposits Along the Neosho River}

The occurrence of exposed basal gravel deposits in the banks of the Neosho River was assessed by the onsite inspection of seven representative river reaches that together provide about a 24-percent sample of the Neosho River in Kansas downstream from John Redmond Reservoir (fig. 1). The reaches inspected varied substantially as to the occurrence of exposed basal gravel deposits, ranging from about $55 \mathrm{ft} / \mathrm{mi}$ (or about 1 percent of the reach) for the Chanute reach to about 1,800 ft/mi (or about 35 percent of the reach) for the Oswego reach. Overall, the mean extent was about $940 \mathrm{ft} / \mathrm{mi}$ (or about 18 percent of the total river miles inspected) (table 5). However, because some of the basal gravel deposits likely were not observed (for example, due to bank slumps, bar deposits, vegetation, debris, riprap, or submergence), the extent of exposed basal deposits reported in table 5 may be somewhat underrepresented. Generally, at any given location, exposed basal gravel deposits were observed on 
(A)

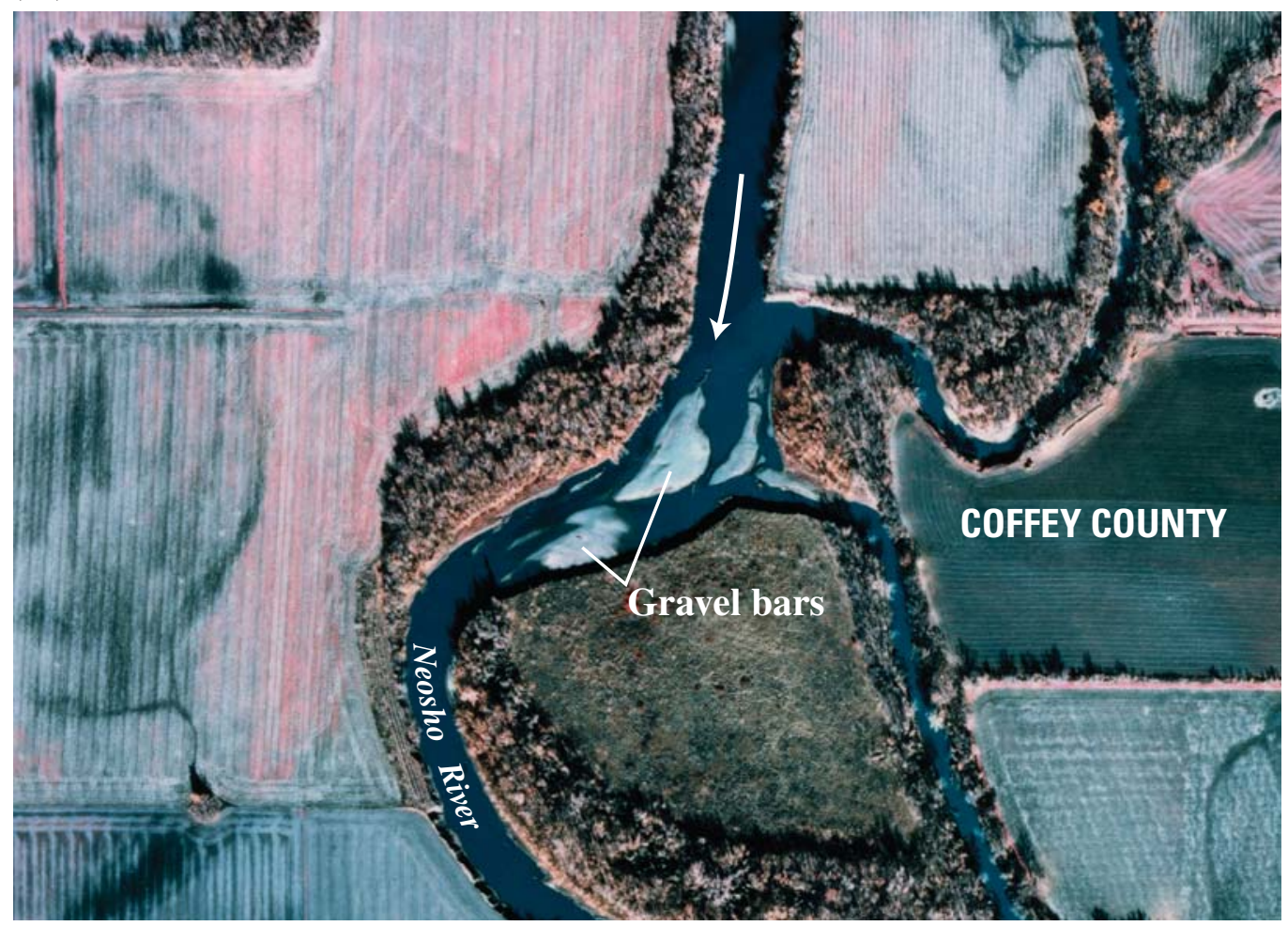

(B)

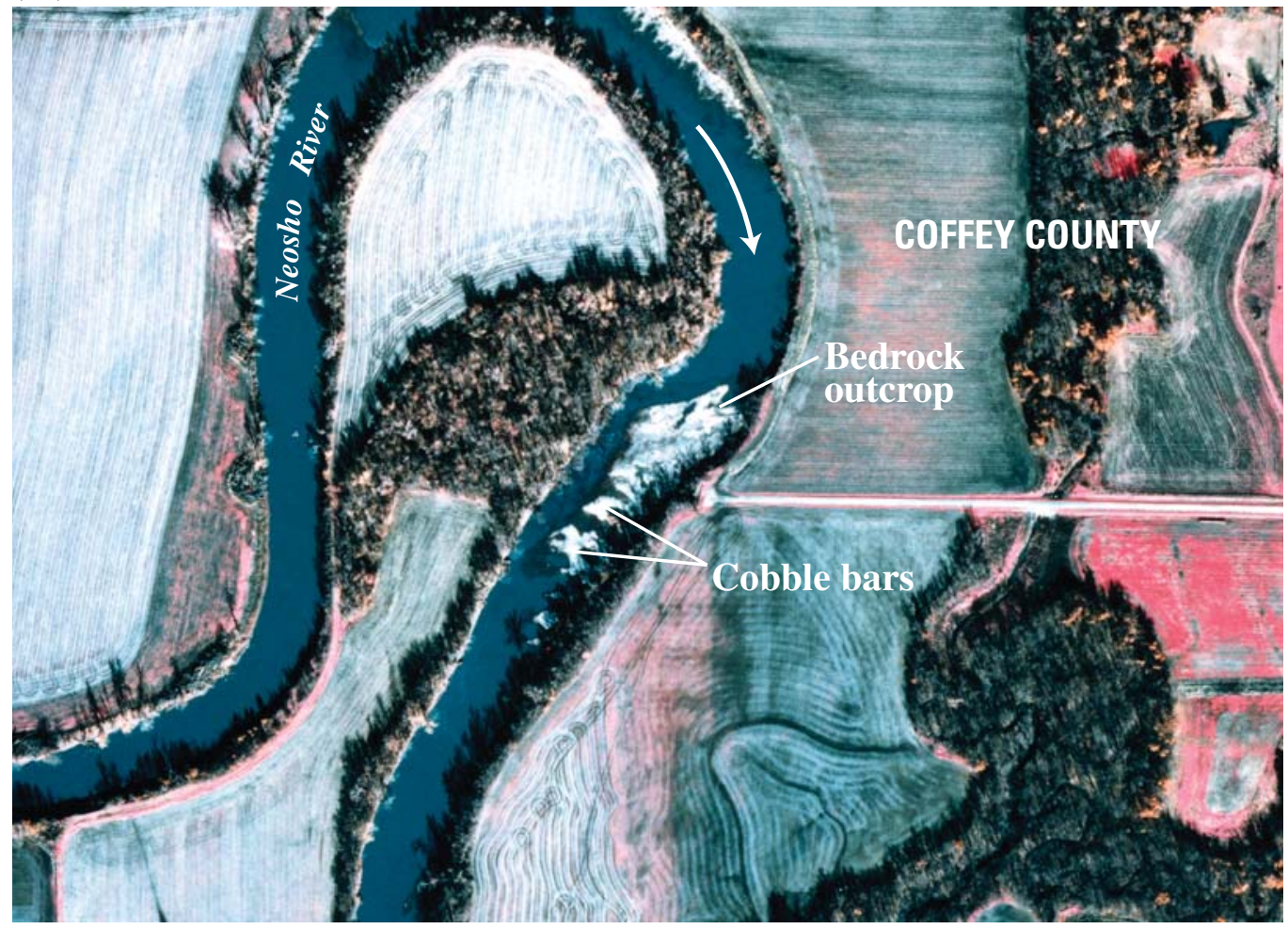

Figure 10. Comparison of bar-deposit shapes in the Neosho River near LeRoy, Kansas, December 3 , 2004. Shown are $(A)$ a series of gravel bars oriented parallel to the direction of flow and $(B)$ cobble bars (downstream from a bedrock outcrop) oriented perpendicular to the direction of flow. Aerial photographs taken by Western Air Maps, Inc. 
Table 5. River reach length and approximate total length, extent, range in maximum thickness, and mean maximum thickness of exposed basal gravel deposits in channel banks of the Neosho River in Kansas downstream from John Redmond Reservoir, 2004.

[ft/mi, feet per mile; ft, feet; <, less than; all values rounded to 1 or 2 significant figures]

\begin{tabular}{|c|c|c|c|c|}
\hline $\begin{array}{l}\text { River reach name and number } \\
\text { (length of reach, in miles) } \\
\text { (fig. 1) }\end{array}$ & $\begin{array}{l}\text { Approximate total } \\
\text { length of exposed } \\
\text { basal gravel } \\
\text { deposits } 1, \text { in feet } \\
\text { (percent, } \% \text {, of } \\
\text { reach) }\end{array}$ & $\begin{array}{l}\text { Approximate extent } \\
\text { of exposed basal } \\
\text { gravel deposits per } \\
\text { river mile }{ }^{1} \\
\text { (ft/mi) }\end{array}$ & $\begin{array}{l}\text { Approximate range } \\
\text { in maximum } \\
\text { thckness of exposed } \\
\text { basal gravel } \\
\text { deposits above low- } \\
\text { flow water surface } \\
\text { (ft) }\end{array}$ & $\begin{array}{l}\text { Approximate mean } \\
\text { maximum thickness } \\
\text { of exposed basal } \\
\text { gravel deposits } \\
\text { above low-flow } \\
\text { water surface (ft) }\end{array}$ \\
\hline Burlington reach 1 (6.2) & $\begin{array}{l}6,200 \\
(19 \%)\end{array}$ & 1,000 & $<1-6$ & 3 \\
\hline Neosho Falls reach 2 (6.3) & $\begin{array}{l}4,400 \\
(13 \%)\end{array}$ & 700 & $<1-8$ & 3 \\
\hline Humboldt reach 3 (6.3) & $\begin{array}{l}2,800 \\
(8 \%)\end{array}$ & 440 & $1-10$ & 3 \\
\hline Chanute reach 4 (4.5) & $\begin{array}{c}250 \\
(1 \%)\end{array}$ & 55 & $1-3$ & 2 \\
\hline Erie reach 5 (5.4) & $\begin{array}{l}4,400 \\
(15 \%)\end{array}$ & 810 & $1-7$ & 3 \\
\hline Parsons reach 6 (6.3) & $\begin{array}{l}8,400 \\
(25 \%)\end{array}$ & 1,300 & $<1-10$ & 3 \\
\hline Oswego reach 7 (7.6) & $\begin{array}{l}14,000 \\
(35 \%)\end{array}$ & 1,800 & $<1-9$ & 4 \\
\hline Combined (42.6) & $\begin{array}{c}40,000 \\
(\text { mean } 18 \%)\end{array}$ & $\begin{array}{r}940 \\
(\text { mean })\end{array}$ & $<1-10$ & 3 \\
\hline
\end{tabular}

\footnotetext{
${ }^{1}$ Because some basal gravel deposits likely were not observed (for example, due to bank slumps, bar deposits, vegetation, debris, riprap, or submergence), the total length and extent values reported may be somewhat underrepresented.

${ }^{2}$ Maximum thickness of basal gravel deposits above low-flow water surface was visually estimated.
}

a single bank if at all. Sites at which basal deposits were observed simultaneously on both banks were rare. The distribution of exposed basal gravel deposits for each of the seven reaches is shown in figures 11 to 17 .

Lengths of individual exposed basal gravel deposits ranged from less than $50 \mathrm{ft}$ to several hundred feet. The longest exposed deposit, observed in the Oswego reach (fig. 1C), had an estimated length of about $1,900 \mathrm{ft}$. The mean length of the exposed deposits was not estimated for the individual river reaches because of occasional uncertainty as to whether a series of closely spaced deposits represented multiple deposits or a single long deposit that was partially obscured (for example, by bank slumps and so forth).

Estimated maximum thicknesses of the exposed basal gravel deposits above the low-flow water surface ranged from less than 1 to about $10 \mathrm{ft}$. Overall, the mean maximum thickness was about $3 \mathrm{ft}$ (table 5). Occasionally, the basal deposits were short with tapered ends and resembled a cross section of a large gravel bar. Frequently, the basal deposits were relatively long with an upper surface that was flat. For this type of deposit, the estimated maximum thickness often provided an approximation of the mean thickness. An example of an exposed basal deposit in the Oswego reach (located on the opposite bank from site B-2, fig. 1C) is shown in figure 18. Given that the Neosho River channel bed frequently is situated on or near bedrock, the observed average thicknesses appear to be consistent with previous publications in which the average thickness of the basal gravel deposits was stated to be about $3 \mathrm{ft}$ (Jungmann, 1966; Miller, 1969; Morton and Fader, 1972).

The composition of the basal gravel deposits observed in the seven representative reaches generally was consistent with the in-channel gravel bars. That is, the basal deposits consisted of similarly sized gravel that was predominantly brownish, rounded chert. 


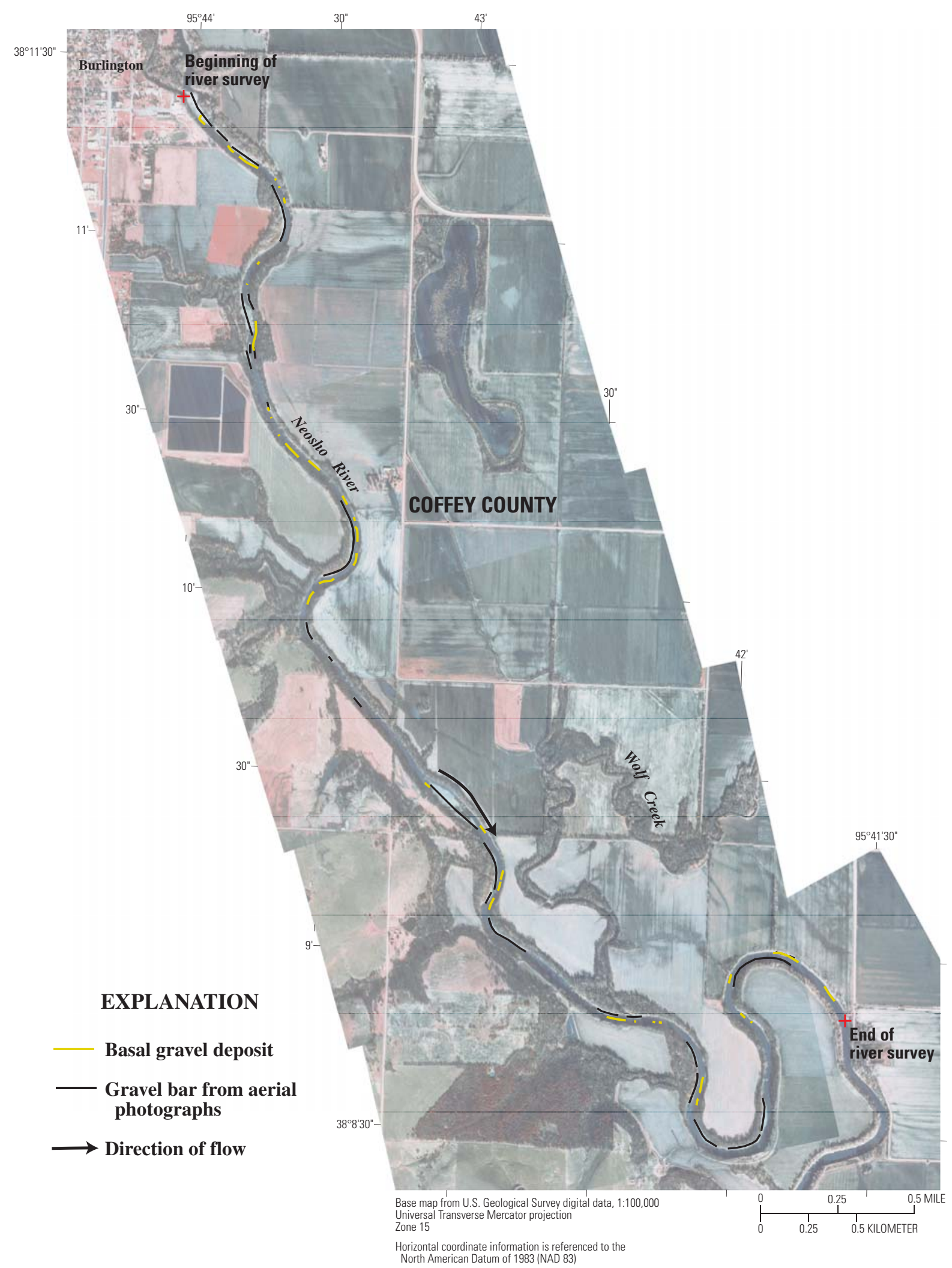

Figure 11. Distribution of exposed basal gravel deposits (from onsite inspection) and apparent gravel bars (from aerial photographs) in the Neosho River for the representative reach located near Burlington. Location of river reach shown in figure 1 B. Aerial photographs taken December 3, 2004, by Western Air Maps, Inc. 


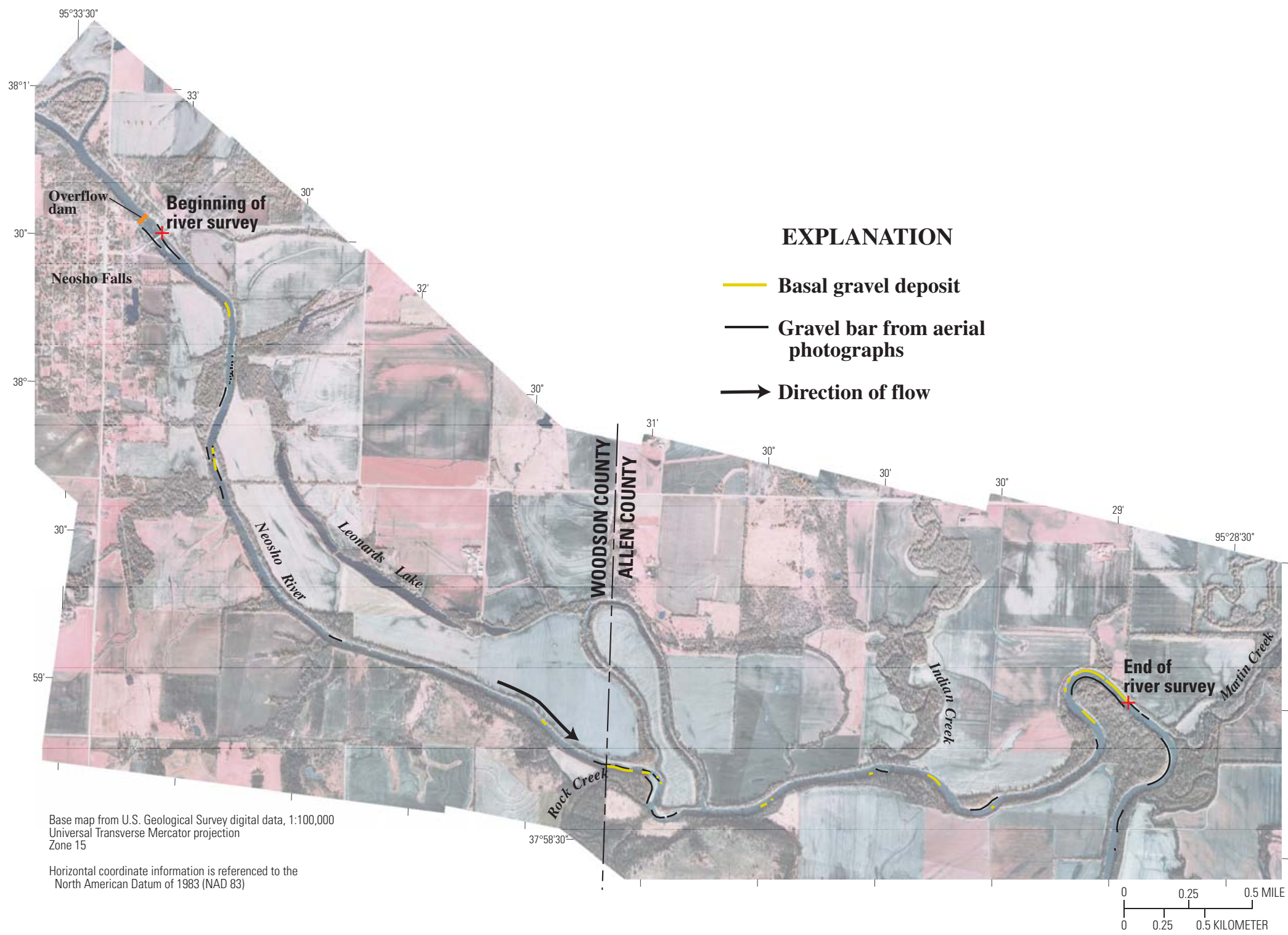

Figure 12. Distribution of exposed basal gravel deposits (from onsite inspection) and apparent gravel bars (from aerial photographs) in the Neosho River for the representative reach located near Neosho Falls. Location of river reach shown in figure 1B. Aerial photographs taken December 3, 2004, by Western Air Maps, Inc. 


\section{EXPLANATION}

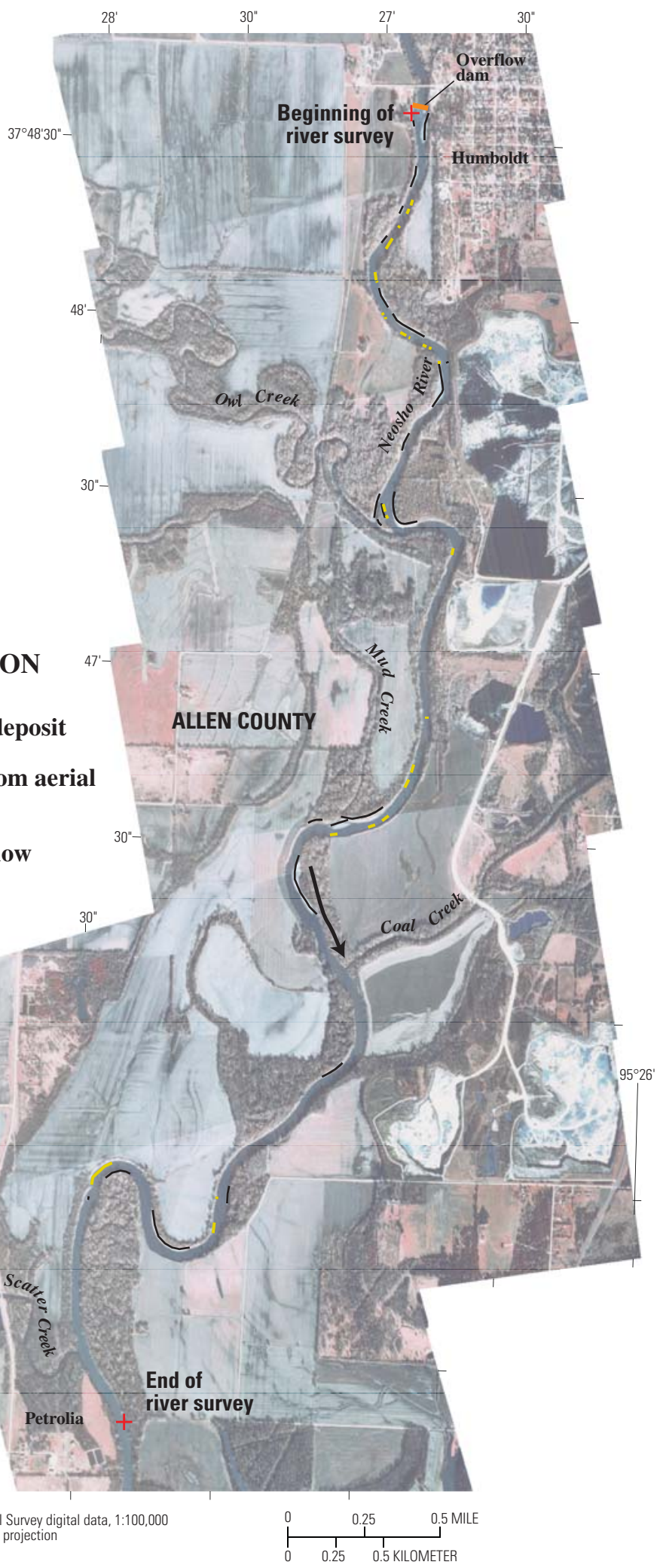

Base map from U.S. Geological Survey digital data, 1:100,000 Universal Transverse Mercator projection

Basal gravel deposit

Gravel bar from aerial photographs

$\longrightarrow$ Direction of flow

Horizontal coordinate information is referenced to the

North American Datum of 1983 (NAD 83)

Figure 13. Distribution of exposed basal gravel deposits (from onsite inspection) and apparent gravel bars (from aerial photographs) in the Neosho River for the representative reach located near Humboldt. Location of river reach shown in figure $1 B$. Aerial photographs taken December 14, 2004, by Western Air Maps, Inc. 


\section{EXPLANATION}

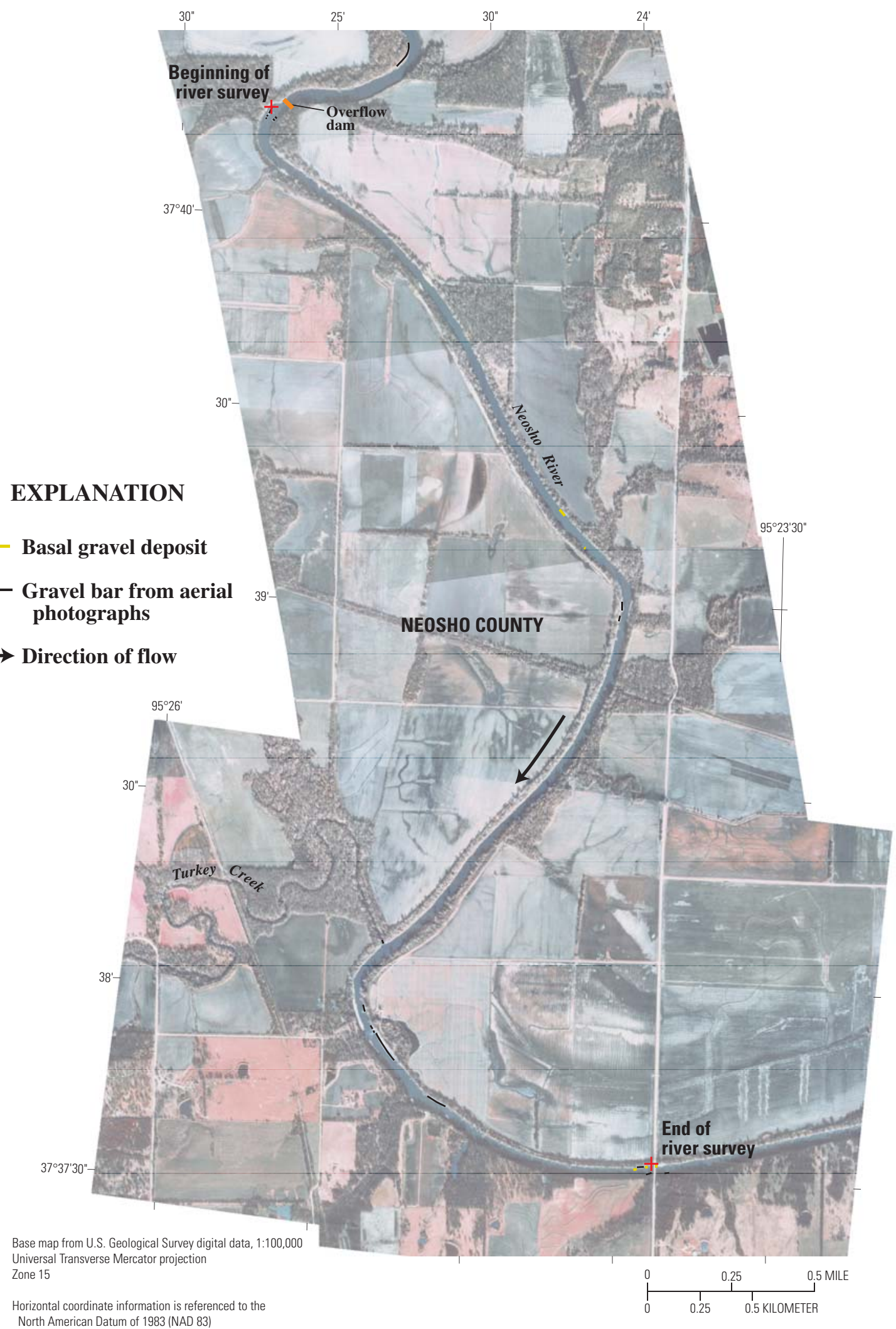

Base map from U.S. Geological Survey digital data, 1:100,000 Universal Transverse Mercator projection

Basal gravel deposit

Gravel bar from aerial photographs

$\longrightarrow$ Direction of flow

Figure 14. Distribution of exposed basal gravel deposits (from onsite inspection) and apparent gravel bars (from aerial photographs) in the Neosho River for the representative reach located near Chanute. Location of river reach shown in figure 1C. Aerial photographs taken December 14, 2004, by Western Air Maps, Inc. 


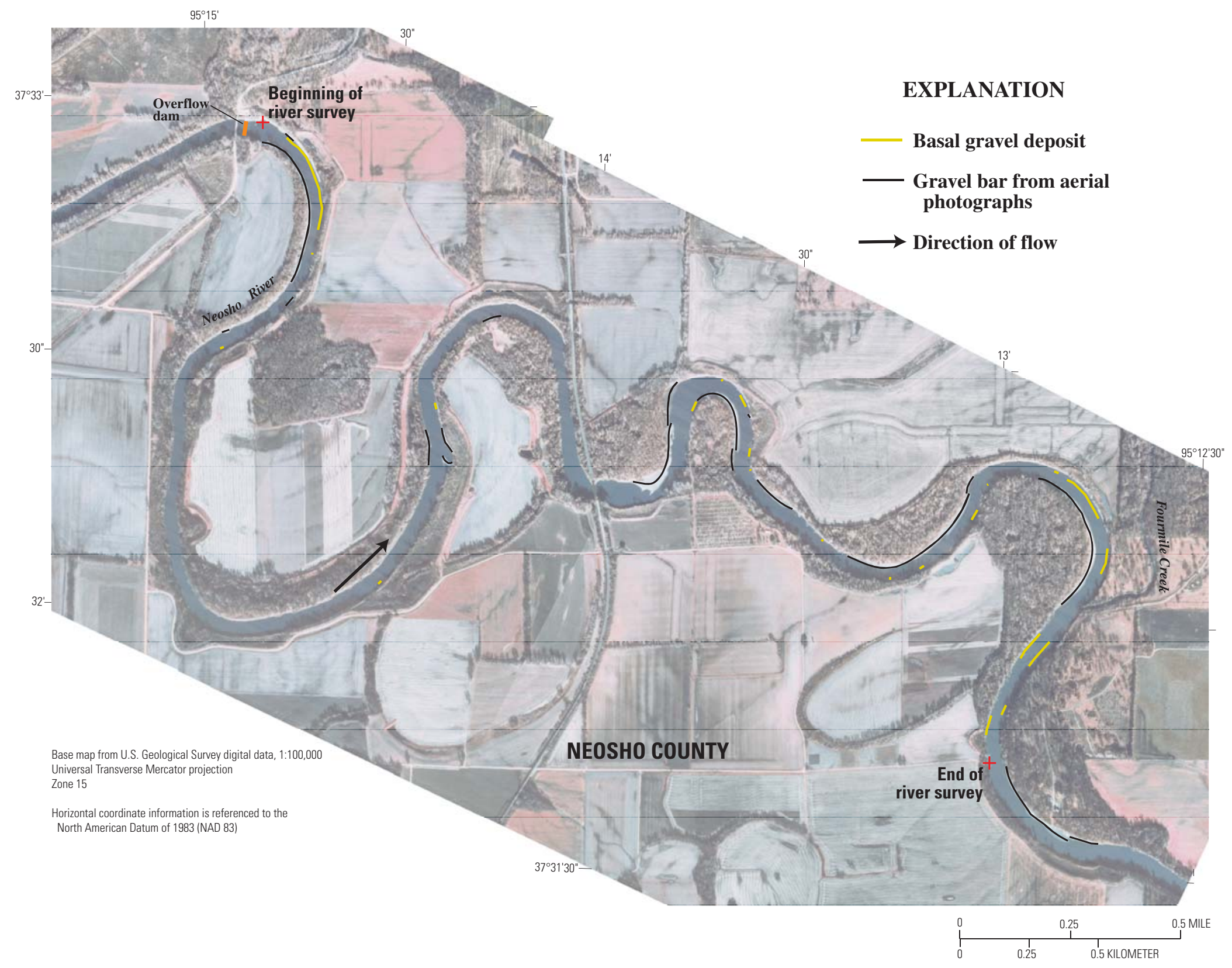

Figure 15. Distribution of exposed basal gravel deposits (from onsite inspection) and apparent gravel bars (from aerial photographs) in the Neosho River for the representative reach located near Erie. Location of river reach shown in figure 1C. Aerial photographs taken December 14, 2004, by Western Air Maps, Inc. 


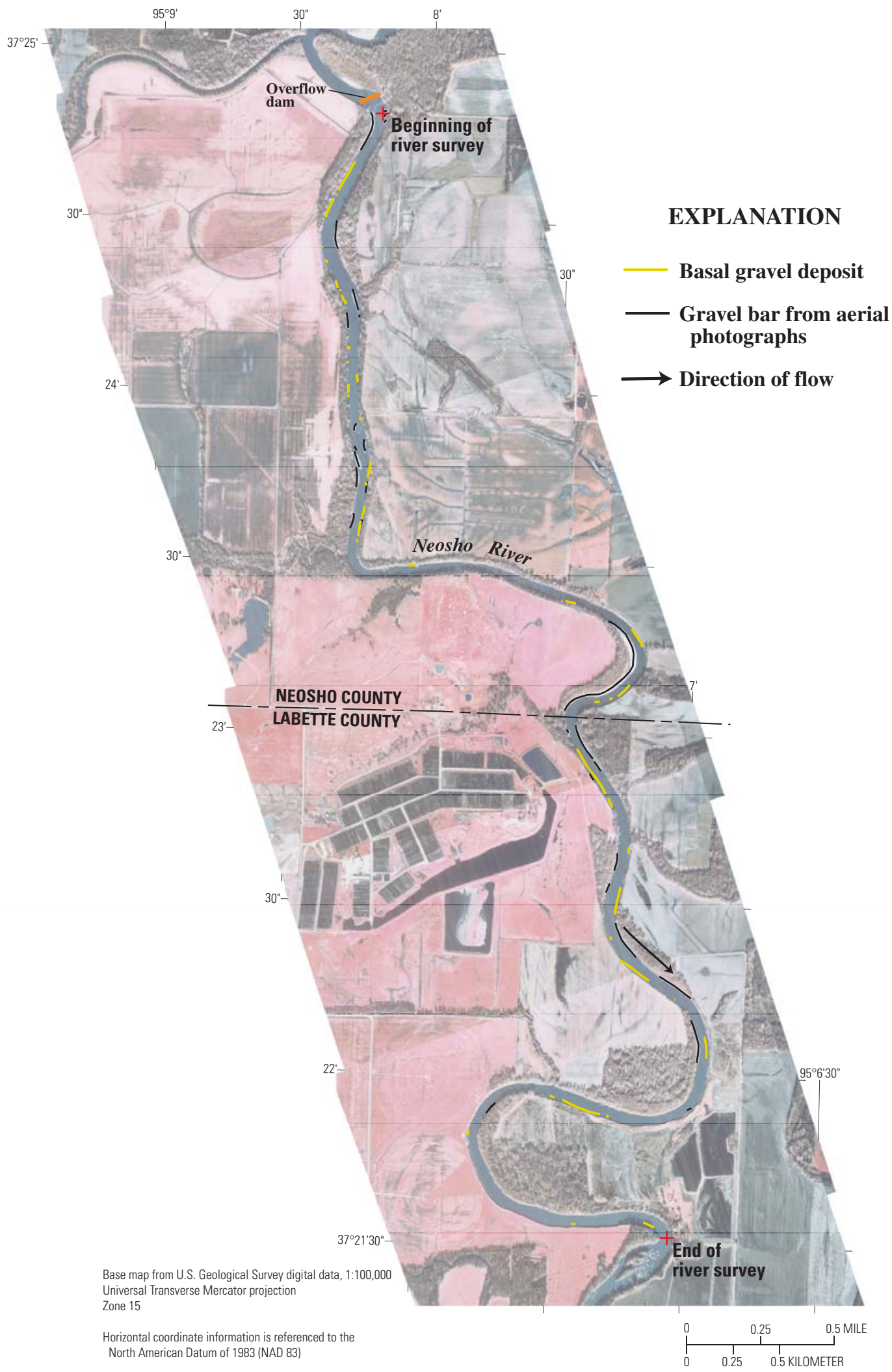

Figure 16. Distribution of exposed basal gravel deposits (from onsite inspection) and apparent gravel bars (from aerial photographs) in the Neosho River for the representative reach located near Parsons. Location of river reach shown in figure 1 C. Aerial photographs taken December 14, 2004, by Western Air Maps, Inc. 


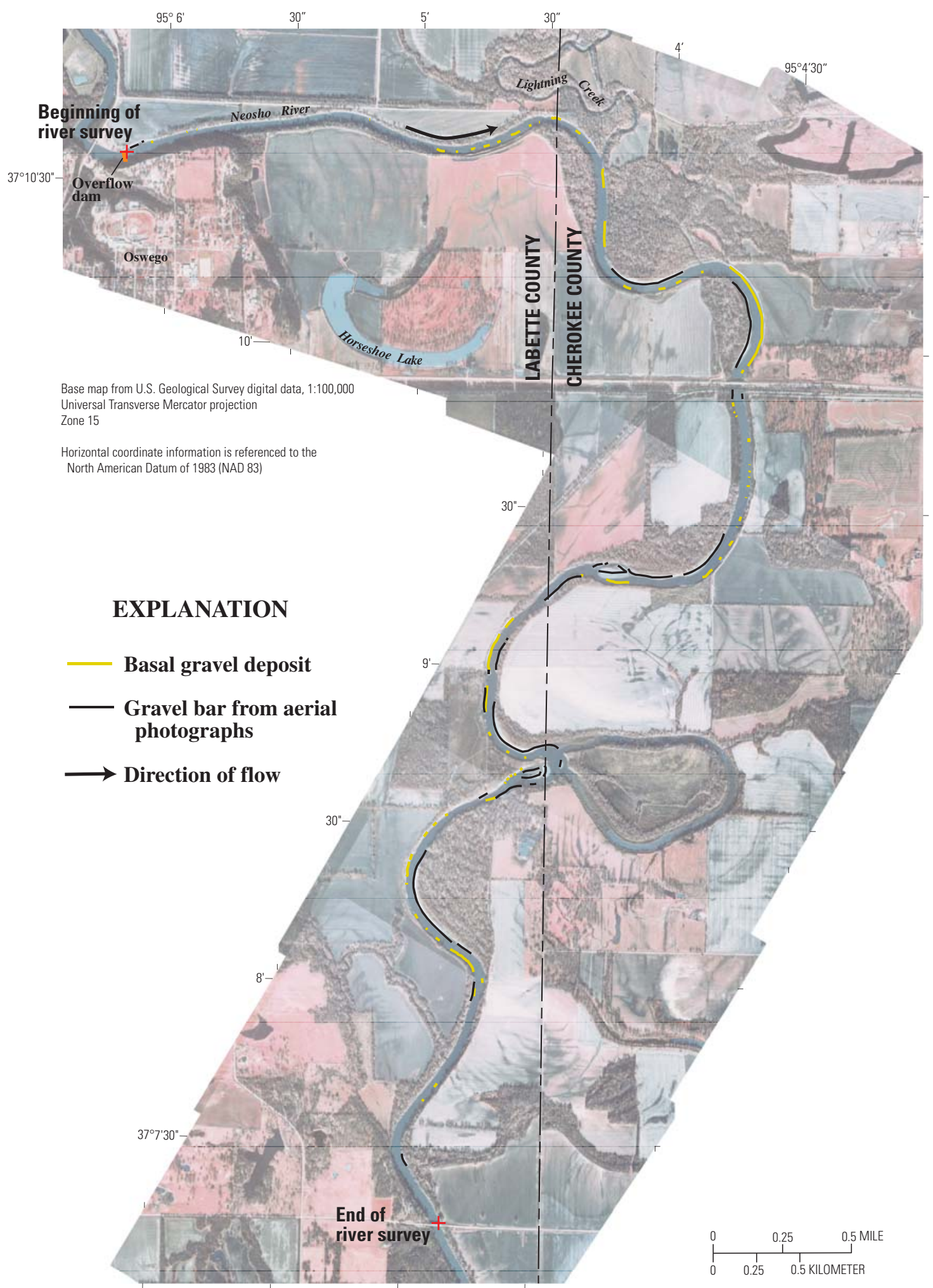

Figure 17. Distribution of exposed basal gravel deposits (from onsite inspection) and apparent gravel bars (from aerial photographs) in the Neosho River for the representative reach located near Oswego. Location of river reach shown in figure $1 C$. Aerial photographs taken December 14, 2004, by Western Air Maps, Inc. 


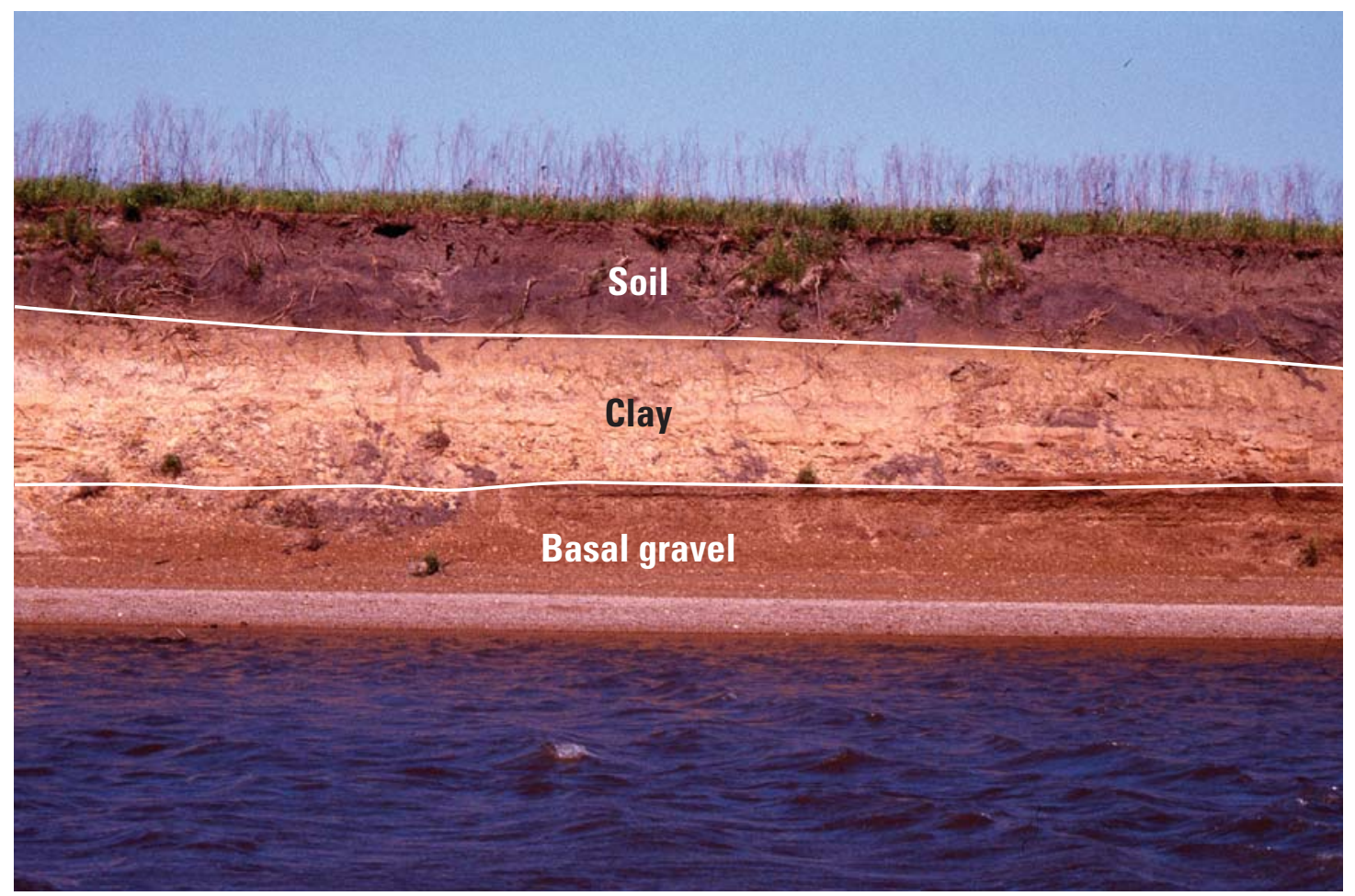

Figure 18. Basal gravel deposit exposed on a cutbank located on the opposite side of the Neosho River channel from gravel bar sampling site B-2 (Oswego reach). Location of sampling site shown in figure $1 \mathrm{C}$. Photograph taken on May 6, 2004.

\section{Gravel Sources for the Neosho River}

In this section, the results of the analyses are interpreted to provide an assessment of the potential of tributaries and basal channel-bank deposits to provide sources of gravel for the Neosho River in Kansas downstream from John Redmond Reservoir. Additional topics discussed include the effect of dams on sources of Neosho River gravel and the future of Neosho River gravel bars.

\section{Assessment of Potential Sources of Chert Gravel}

Because the gravel bars in the Neosho River in Kansas are composed predominantly of chert (table 3 ), this discussion is focused on the potential sources of chert. Overall, the tributaries to the Neosho River do not provide a substantial source of chert gravel to the river. For 15 of the 18 streams inspected (fig. 1, table 1), little or no chert was observed at most or all of the inspection sites. Moreover, the absence of a bar deposit of gravel in the Neosho River at or immediately downstream from its confluence with each of the 15 streams indicated that they are not a major source of gravel to the river. Likewise, for two of the three streams for which substantial chert was observed at several inspection sites, a gravel bar in the Neosho River at or immediately downstream from the confluence was not evident. The only tributary for which substantial chert was observed at most of the inspection sites, and a large chert gravel bar exists at its confluence with the Neosho River, is Indian Creek (fig. 19). Thus, Indian Creek was the only tributary inspected that potentially may provide a substantial input of chert gravel to the river.

Two possibilities may account for the apparent lack of gravel transport from the tributaries into the Neosho River. First, the amount of available gravel, and the frequency and duration of the flows required to transport it, may be insufficient to result in large inputs to the river. Frequently, the gravel in the tributaries originates from the erosion of local sources, such as bedrock outcrops. Once eroded, the material may be transported only a short distance downstream from the source before being deposited. Once deposited, the size of the material and (or) compaction (for example, by silt and sand) may render the material very resistant to further transport except during the largest flows. Second, the non-chert material (that is, limestone, shale, and sandstone) is less durable (compared to chert) when subjected to erosional and transport processes in the fluvial environment. Thus, much of the non-chert gravel may be broken down before it reaches the Neosho River. These interpretations are supported by the fact that minimal amounts of nonchert gravel typically were observed in the Neosho River gravel bars (table 3).

The basal chert gravel deposits appear to be the major present-day source of chert for the Neosho River channel. Basal chert gravel deposits were found in all the reaches visually 


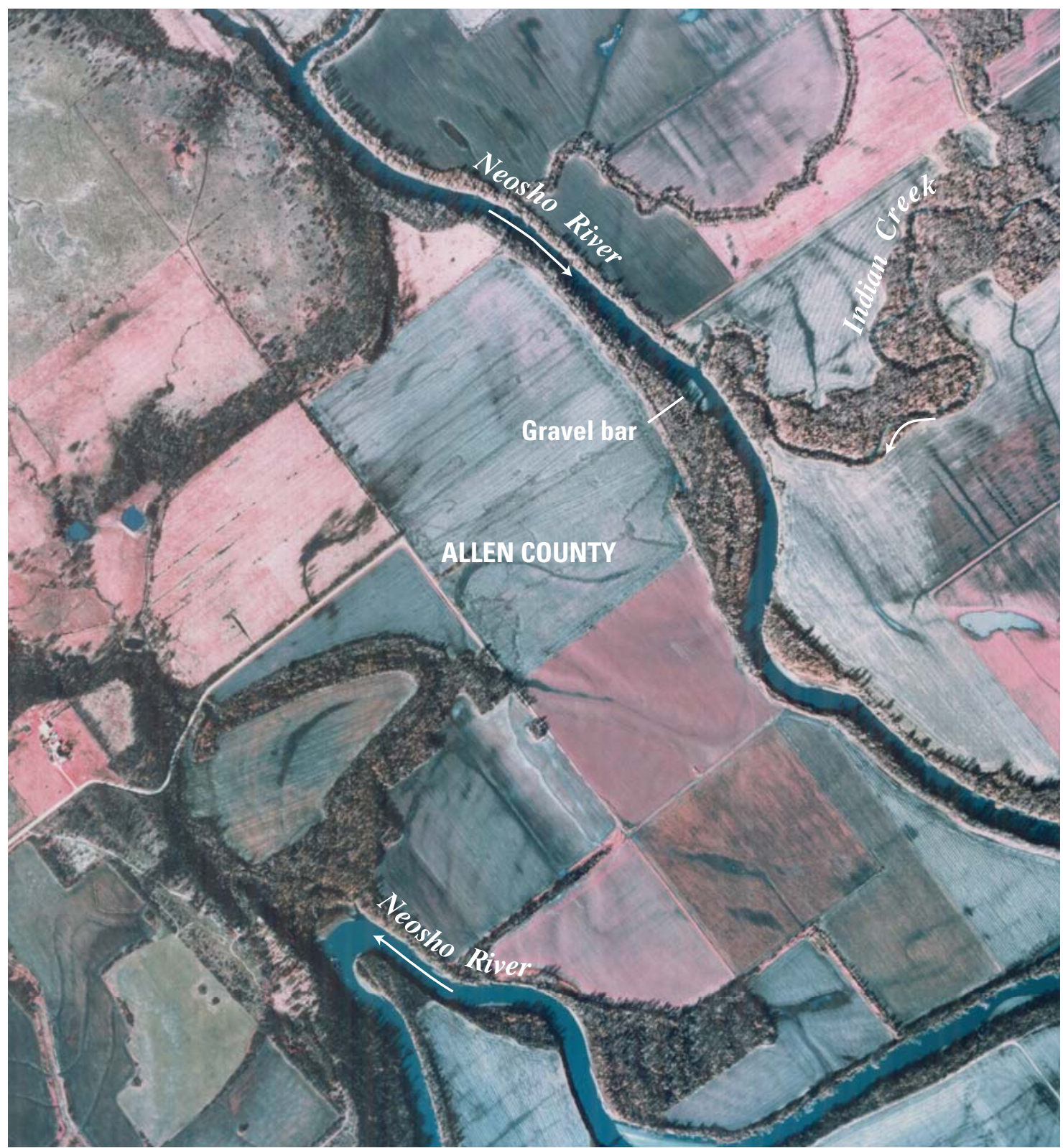

Figure 19. Aerial photograph of gravel bar in the Neosho River at its confluence with Indian Creek. Arrows on aerial photograph indicate direction of streamflow. Location of Indian Creek shown in figure 1B. Aerial photograph taken December 3, 2004, by Western Air Maps, Inc.

inspected (figs. 11-17), and a statistically significant relation was indicated between the occurrence of the basal deposits and the occurrence of chert gravel bars (see information provided in the following section). Particle-size analyses of the basal deposits were not performed due to problems with obtaining a random sample. However, grab samples of the chert from the basal deposits and from gravel bars just downstream from the basal deposits appeared to be similar. The basal deposits are a finite source of chert gravel for the Neosho River.

The upland chert gravel deposits (fig. 3) represent another possible source for the Neosho River. However, given the dis- tance between these upland deposits and the active Neosho River channel, they are not considered to be a viable source of chert gravel.

Bedrock outcrops of limestone, usually located at riffles along the Neosho River, can provide a source of cobble- and gravel-sized material for bar deposits at or just downstream from the riffles. A small percentage of these softer limestone materials show up in some Neosho River bar deposits and can constitute 5 to 15 percent of the total gravel (table 3 ). None of the basal gravel deposits sampled contained any limestone. 


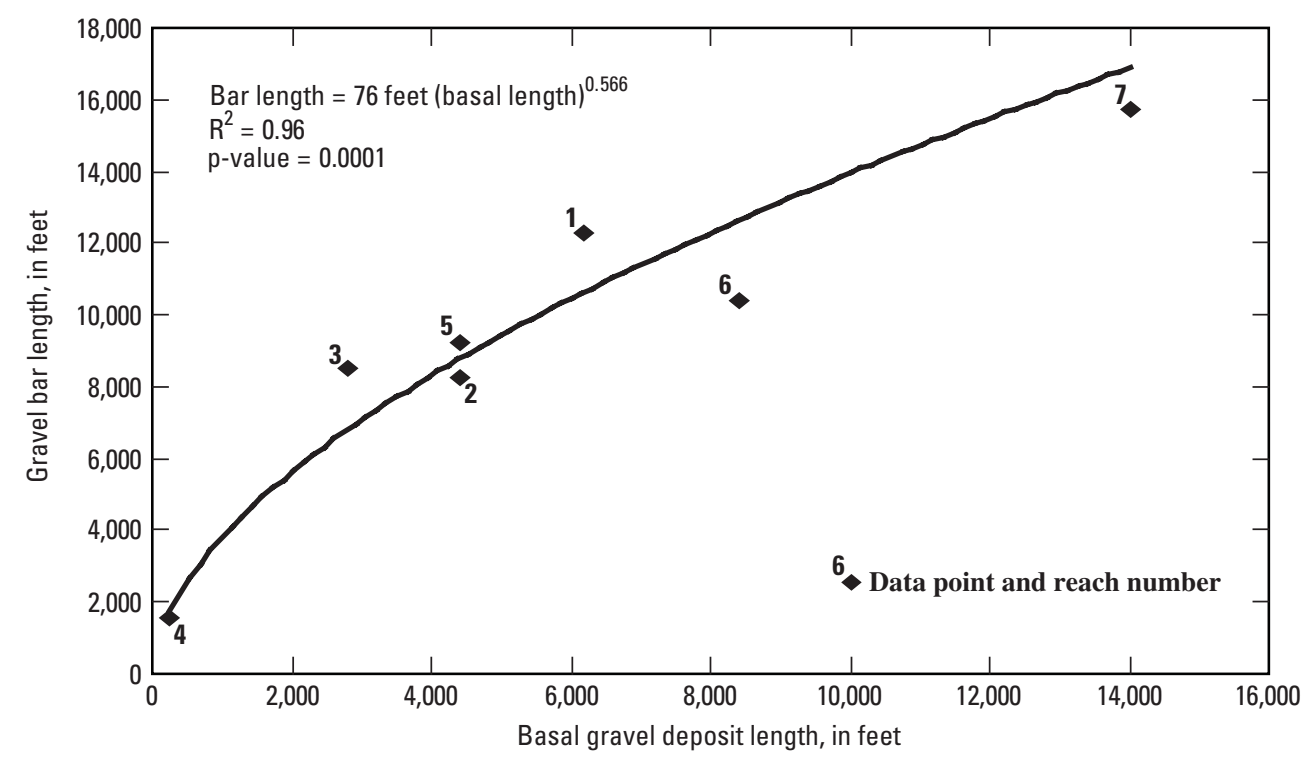

Figure 20. Relation between total basal gravel deposit length and total apparent gravel bar length for the seven Neosho River reaches inspected. Location of river reaches shown in figure 1.

\section{Relation of Basal Gravel Deposit Length to Apparent Gravel Bar Length}

A statistically significant relation was indicated between the length of basal gravel deposits and the length of apparent gravel bars in the Neosho River. The total length of the observed basal gravel deposits was compared with the total length of apparent gravel bars (estimated from the aerial photographs) for each of the seven representative reaches that were inspected (figs. 11-17). In a regression of the data, a significant relation $\left(\mathrm{R}^{2}=0.96\right.$, $\mathrm{p}$-value $\left.=0.0001\right)$ exists between total basal gravel deposit lengths and total apparent gravel bar lengths (fig. 20). As the total length of the basal gravel deposits increases so does the total length of the apparent gravel bars. The regression equation is:

$$
y=76 x^{0.566},
$$

where $y$ is the total apparent gravel bar length (in feet), and $x$ is the total length of the basal gravel deposits (in feet).

A comparison of the location of the basal deposits and the apparent gravel bars for the seven representative reaches inspected indicated that the gravel bars frequently occur immediately downstream from the basal deposits. This observation suggests that the gravel is eroded from a basal deposit and subsequently deposited in the first favorable location downstream (that is, typically a point bar). For the upstream three representative reaches (fig. 1B), a comparison of the 2004 aerial photographs with 1991 aerial photographs indicated that there has been little change in the location and extent of the gravel bars. Several large flows (with an estimated recurrence interval of 2 to 5 years) on the Neosho River between 1991 and 2004 did not appear to substantially change the location or extent of the gravel bars in these reaches. On the basis of this evidence, combined with the observation that one mined gravel bar has experienced minimal replenishment since 1998 (Chauncey Shepard, Valley Gravel Co., oral commun., 2005), it is reasonable to conclude that the erosional and depositional processes responsible for gravel-bar formation occur infrequently.

Given that large, sustained flows are required for substantial gravel erosion and transport to occur, several months or years may elapse between successive substantial movements of gravel in a river. Andrews and Nankervis (1995) state that bedload in gravel-bed streams typically is transported only about 5 to 10 percent of the time during the largest flows. Thus, given the typically infrequent occurrence of gravel-transporting flows, the time required for a gravel bar to rebuild to its premined size may require up to several years. The exact time required will depend on the frequency, magnitude, and duration of gravel-transporting flows.

\section{Effect of Dams on Neosho River Gravel}

John Redmond Reservoir has been identified as a possible trap for gravel moving downstream in the upper part of the Neosho River Basin. This study indicates that basal deposits are an important source of gravel along the Neosho River and, once eroded, the gravel from these deposits may be transported only a short distance before subsequent redeposition. Thus, John Redmond Reservoir may have only a minor effect on the supply of gravel to gravel bars downstream from the reservoir over a period of years to decades unless a very large flow occurs.

The overflow dams likely have some effect on gravel transport and deposition. For example, the backwater area 
upstream from an overflow dam may cause enhanced gravel deposition. Investigation of gravel deposition upstream from the overflow dams was beyond the scope of this study.

\section{The Future of Neosho River Gravel Bars}

The relation between total basal gravel deposit length and total apparent gravel bar length (fig. 20) indicates that the Neosho River gravel bars are directly associated with upstream basal deposits of chert gravel in the channel banks. These basal gravel deposits are common throughout the Neosho River flood plain as evidenced by the seven representative reaches inspected, the presence of gravel pits on the flood plain (identified on several USGS 7.5-minute topographic quadrangle maps), and information from well driller's logs of water wells in the flood plain (Jungmann, 1966; Miller, 1969).

Available evidence indicates that the chert gravel is moving downstream but only intermittently and mostly during infrequent large flows. Replenishment of mined gravel bars first requires the availability of basal gravel deposits upstream (that is, a source). Then, flows of sufficient magnitude and duration are required to erode and transport the gravel to the deposition area. As evidenced by the differences in channel location between the older topographic maps and 2004 aerial photographs, the rate of channel migration is variable. For some river reaches the channel has been essentially static, whereas other reaches have experienced relatively substantial channel movement. Historic channel migration can provide an indication of the rate at which the gravel in basal deposits is being eroded.

The chert gravels that currently (2004) characterize bar deposits in the Neosho River channel likely have been eroded and deposited several times over the centuries, each time moving farther downstream. In the future, the Neosho River will continue to erode the basal deposits and deposit the chert gravels in downstream bars. The chert gravel bars typically will be slow (up to several years) to recover from in-channel gravel mining unless a very large flow occurs shortly after mining.

\section{Conclusions}

A combination of remotely sensed and onsite evidence obtained in 2004 was used to characterize and assess the potential of tributaries and main-stem basal deposits as sources of gravel for the Neosho River downstream from John Redmond Reservoir in Kansas. The major conclusions of this study are listed below:

1. Gravel in the Neosho River channel consists predominantly of brownish, rounded chert that is medium to coarse grained in size.

2. The major present-day source of chert gravel for the Neosho River channel is the basal deposits that are common in the flood plain of the Neosho River.
3. With the possible exception of Indian Creek, the tributaries of the Neosho River do not provide a substantial input of chert gravel to the river.

4. The small percentage of non-chert gravel in Neosho River bar deposits mostly originates from bedrock outcrops within the channel.

5. The total length of apparent gravel bars in the Neosho River is related to the total length of basal gravel deposits along the channel.

6. Gravel-bar formation within the Neosho River channel is an intermittent process that mostly occurs in association with infrequent large flows.

7. Chert gravel bars in the Neosho River may require up to several years to recover from in-channel gravel mining unless a very large flow occurs shortly after mining.

8. John Redmond Reservoir likely has little downstream effect on sources of gravel to the Neosho River over a period of years to decades unless a very large flow occurs upstream from the reservoir.

9. Ultimately, the chert gravel in the Neosho River is essentially a finite resource as its primary present-day source appears to be the finite basal deposits.

\section{References Cited}

Aber, J.S., 1997, Chert gravel and Neogene drainage in eastcentral Kansas: Kansas Geological Survey, Current Research in Earth Sciences, Bulletin 240, part 3, p. 29-41.

Andrews, E.D., and Nankervis, J.M., 1995, Effective discharge and the design of channel maintenance flows for gravel-bed rivers, in Costa, J.E., Miller, A.J., Potter, K.W., and Wilcock, P.R., eds., Natural and anthropogenic influences in fluvial geomorphology: Washington, D.C., American Geophysical Union, Geophysical Monograph 89, p. 151-164.

Beeson, C.E., and Doyle, P.F., 1995, Comparison of bank erosion at vegetated and non-vegetated channel bends: Water Resources Bulletin, v. 31, no. 6, p. 983-990.

Buchanan, Rex, ed., 1984, Kansas geology_an introduction to landscapes, rocks, minerals, and fossils: Lawrence, Kansas, University Press of Kansas, 208 p.

Byerley, R.D., 1995, Chert gravel sources, hydrology, transportation, and deposition within the lower Neosho River, southeastern Kansas: Emporia, Kansas, Emporia State University, master's thesis, $78 \mathrm{p}$.

Carswell, W.J., and Hart, R.J., 1985, Transit losses and traveltimes for reservoir releases during drought conditions along the Neosho River from Council Grove Lake to Iola, eastcentral Kansas: U.S. Geological Survey Water-Resources Investigations Report 85-4003, 40 p. 
Church, M.A., McClean, D.G., and Wolcott, J.F., 1987, River bed gravels - sampling and analysis, chap. 3, in Thorne, C.R., Bathurst, J.C., and Hey, R.D., eds., Sediment transport in gravel-bed rivers: New York, John Wiley, p. 43-88.

ESRI, 2004, ArcGIS version 9.0: Redlands, California, Environmental Systems Research Institute, various pagination.

Fenneman, N.M., 1946, Physical divisions of the United States: U.S. Geological Survey special map, scale 1:7,000,000, 1 sheet.

Frye, J.C., 1955, The erosional history of the Flint Hills: Transactions Kansas Academy of Science, v. 58, p. 79-86.

Gordon, N.D., McMahon, T.A., and Finlayson, B.L., 1992, Stream hydrology — an introduction for ecologists: New York, John Wiley \& Sons, 526 p.

High Plains Regional Climate Center, 2004, Historical data summaries: Information available on the Web, accessed February 20, 2004, at http://www.hprcc.unl.edu/

Hodge, H.C., and McKay, J.H., 1934, Micro hardness of minerals comprising the Mohs scale: American Mineralogist, v. 19, p. 161-168.

Judson, Sheldon, and Kauffman, M.E., 1990, Physical geology (8th ed.): Englewood Cliffs, New Jersey, Prentice Hall, $534 \mathrm{p}$.

Jungmann, W.L., 1966, Geology and ground-water resources of Neosho County, Kansas: Kansas Geological Survey Bulletin 183, December 1966, 46 p.

Juracek, K.E., 1999, Geomorphic effects of overflow dams on the lower Neosho River, Kansas: U.S. Geological Survey Water-Resources Investigations Report 99-4147, 6 p.

Juracek, K.E., 2000, Channel stability downstream from a dam assessed using aerial photographs and stream-gage information: Journal of the American Water Resources Association, v. 36, no. 3, p. 633-645.

Kansas Applied Remote Sensing Program, 1993, Kansas land cover data base, 1:100,000 scale: Lawrence, Kansas, Data Access and Support Center, available on CD.

Kansas Data Access and Support Center, 2005, Digital orthophotos: Information available on the Web, accessed April 5, 2005, at http://www.kansasgis.org/

Kansas Geological Survey, 1964, Geologic map of Kansas: Kansas Geological Survey map M-1, scale 1:500,000.

Kansas Water Office, 1993, Fiscal year 1995 Kansas Water Plan, Neosho Basin section, Neosho stream corridor subsection: Topeka, Kansas, 8 p.

Kondolf, G.M., 1997, Application of the pebble count-notes on purpose, method, and variants: Journal of the American Water Resources Association, v. 33, no. 1, p. 79-87.

Marcher, M.V., Kenny, J.F., and others, 1984, Hydrology of area 40, Western Region, Interior Coal Province, Kansas, Oklahoma and Missouri: U.S. Geological Survey WaterResources Investigations, Open-File Report 83-266, 97 p.
Miller, D.E., 1969, Geology and ground-water resources of Allen County, Kansas: Kansas Geological Survey Bulletin 195, December 1969, 50 p.

Morton, R.B., and Fader, S.W., 1972, Ground water in the Grand (Neosho) River Basin, Kansas and Oklahoma: U.S. Geological Survey Open-File Report 75-366, 35 p.

O'Conner, H.G., 1953, Geology, mineral resources, and groundwater resources of Lyon County, Kansas: Kansas Geological Survey, v. 12, part 1, p. 5-24.

Osterkamp, W.R., and Hedman, E.R., 1981, Channel geometry of regulated streams in Kansas as related to mean discharge, 1970-80: Kansas Water Office Technical Report No. 15, $56 \mathrm{p}$.

Perry, C.A., Wolock, D.M., and Artman, J.C., 2004, Estimates of median flows for streams on the 1999 Kansas Surface Water Register: U.S. Geological Survey Scientific Investigations Report 2004-5032, 219 p.

Schoewe, W.H., 1949, The geography of Kansas: Transactions Kansas Academy of Science, v. 52, p. 261-333.

Studley, S.E., 1996, Changes in high-flow frequency and channel geometry of the Neosho River downstream from John Redmond Dam, southeastern Kansas: U.S. Geological Survey Water-Resources Investigations Report 96-4243, $16 \mathrm{p}$.

TerraServer, 2005, Aerial photography: Information available on the Web, accessed April 20, 2005, at

http://terraserver-usa.com

Thorne, C.R., 1990, Effects of vegetation on riverbank erosion and stability, chap. 10, in Thornes, J.B., ed., Vegetation and erosion, processes and environments: New York, John Wiley \& Sons, p. 125-144.

U.S. Army Corps of Engineers, 1965, Flood plain information, Neosho and Cottonwood Rivers, Kansas: Tulsa, Oklahoma, U.S. Army Corps of Engineers, Tulsa District, June 1965, $25 \mathrm{p}$.

U.S. Army Corps of Engineers, 1972, Memorandum of findings, riverbank stabilization study, Grand (Neosho) River, Kansas \& Oklahoma, John Redmond Dam \& Reservoir to Kansas-Oklahoma State line: Tulsa, Oklahoma, U.S. Army Corps of Engineers, Tulsa District, September 1972, 24 p.

U.S. Fish and Wildlife Service, 1991, Neosho madtom recovery plan: U.S. Fish and Wildlife Service, 42 p.

U.S. Fish and Wildlife Service, 2004, The endangered species program: Information available on the Web, accessed December 28, 2004, at http://endangered.fws.gov/

Wentworth, C.K., 1922, A scale of grade and class terms for clastic sediments: Journal of Geology, v. 30, p. 377-392.

Williams, C.C., 1944, Ground-water conditions in the Neosho River Valley in the vicinity of Parsons, Kansas: Kansas Geological Survey Bulletin 52, part 2, March 15, 1944, 80 p.

Wolman, M.G., 1954, A method of sampling coarse river-bed material: Transactions, American Geophysical Union, v. 35, no. 6, p. 951-956. 
Supplemental Information 
Table 6. Particle-size data for gravel in bar deposits sampled in selected tributaries to the Neosho River in Kansas, 2004.

[mm, millimeters; --, not present in sample]

\begin{tabular}{|c|c|c|c|c|c|c|c|c|}
\hline $\begin{array}{l}\text { Tributary } \\
\text { inspection site } \\
\text { number } \\
\text { (fig. 1) }\end{array}$ & \multicolumn{7}{|c|}{ Number of surficial particles in each particle-size class ${ }^{1}$} & $\begin{array}{c}\text { Median } \\
\text { particle size } \\
(\mathrm{mm})\end{array}$ \\
\hline
\end{tabular}

Big Creek (Coffey and Woodson Counties)

\begin{tabular}{|c|c|c|c|c|c|c|c|}
\hline 3 & -- & -- & 3 & 62 & 32 & 3 & -- \\
\hline 5 & -- & -- & 6 & 51 & 40 & 3 & -- \\
\hline 7 & -- & -- & 24 & 51 & 24 & 1 & -- \\
\hline 11 & -- & -- & -- & 17 & 66 & 17 & -- \\
\hline 13 & -- & 1 & 16 & 59 & 22 & 2 & -- \\
\hline 15 & -- & -- & 6 & 69 & 24 & 1 & -- \\
\hline 17 & -- & -- & 16 & 58 & 25 & 1 & -- \\
\hline
\end{tabular}

\begin{tabular}{|c|c|c|c|c|c|c|c|}
\hline 2 & -- & -- & 5 & 19 & 55 & 21 & -- \\
\hline 4 & -- & 6 & 28 & 54 & 11 & 1 & -- \\
\hline 7 & -- & -- & 13 & 42 & 36 & 9 & -- \\
\hline 9 & -- & -- & 15 & 45 & 37 & 3 & -- \\
\hline 12 & -- & 6 & 39 & 42 & 13 & -- & -- \\
\hline
\end{tabular}

$\begin{array}{rrr}2 & -- & - \\ 3 & -- & 7 \\ 6 & -- & 4 \\ 11 & 2 & 8 \\ 13 & -- & \end{array}$

7

11

13

3

5

7

$\begin{array}{rrr}1 & -- & - \\ 3 & -- & - \\ 5 & -- & - \\ 7 & -- & - \\ 10 & 1 & 3\end{array}$

$\begin{array}{rrr}1 & -- & 3 \\ 23 & 9 & 18\end{array}$

\begin{tabular}{rrr}
2 & 64 & 33 \\
11 & 47 & 34 \\
14 & 50 & 32 \\
36 & 48 & 5 \\
21 & 45 & 29 \\
\multicolumn{2}{l}{ Cherry Creek (Cherokee County) }
\end{tabular}

$\begin{array}{lll}1 & 39 & 47\end{array}$

$\begin{array}{lll}-- & 19 & 53\end{array}$

$\begin{array}{lll}-- & 5 & 35\end{array}$

$3 \quad 3 \quad 36$

Deer Creek (Allen and Anderson Counties)

$--\quad 1$

-- - -

$-$

$--\quad 5$

$--$

$-$

$-$

3

3

18

33

34

32

29

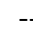

60

7

29

53

Elk Creek (Neosho County)

Elm Creek (Allen County)
Big Creek (Allen and Neosho Counties)

Canville Creek (Allen and Neosho Counties)

8

11

22

22

20

10

26

17

29

73

$\begin{array}{ll}-- & 14\end{array}$

$\begin{array}{lll}28 & -- & 10\end{array}$

$\begin{array}{lll}53 & 7 & 7\end{array}$

$\begin{array}{lll}47 & 11 & 7\end{array}$

32

9

10

14

$\begin{array}{rrrrrr}5 & 29 & 40 & 23 & 3 & 11 \\ 17 & 38 & 36 & 7 & 2 & 16 \\ 5 & 29 & 37 & 26 & 3 & 11 \\ 6 & 33 & 37 & 20 & 4 & 11 \\ 12 & 30 & 36 & 17 & 1 & 13\end{array}$

$\begin{array}{llllll}22 & 49 & 19 & 7 & -- & 23 \\ 26 & 27 & 14 & 4 & 1 & 33\end{array}$


Table 6. Particle-size data for gravel in bar deposits sampled in selected tributaries to the Neosho River in Kansas, 2004.-Continued

[mm, millimeters; --, not present in sample]

\begin{tabular}{|c|c|c|c|c|c|c|c|c|}
\hline $\begin{array}{l}\text { Tributary } \\
\text { inspection site } \\
\text { number } \\
\text { (fig. 1) }\end{array}$ & \multicolumn{7}{|c|}{ Number of surficial particles in each particle-size class ${ }^{1}$} & $\begin{array}{l}\text { Median } \\
\text { particle size } \\
\quad(\mathrm{mm})\end{array}$ \\
\hline
\end{tabular}

Flat Rock Creek $^{3}$ (Crawford and Neosho Counties)

4 -- 1

6 --

$8 \quad--\quad 7$

10

2

11

\section{3}

1

9

24

17

$--\quad 1$

13

14

16

19

2
3
5
7
9

11

1

3

5

1

4

6

8

10

14

16

17

20

21

-- 3

$\begin{array}{ll}-- & 1\end{array}$

-- --

1

$--$

$--$

$--$

$--$

$--$

$--$

$--$

$--$

4

$--$

$--$

$--$

$-$

1

2

$-$

2

--

1

--

$-$

$--$

$--$

--

$$
22
$$$$
7
$$$$
1
$$

1

$$
4
$$

$$
\text { -- }
$$$$
--
$$$$
20
$$$$
3
$$

35

31

11

31

Hickory Creek (Crawford and Labette Counties)

3

$-$

$-$

$-$

--
--
--

12
3
--
9
1

$\begin{array}{rl}44 & 31 \\ 45 & 32 \\ 4 & 30 \\ 31 & 32 \\ 11 & 39\end{array}$

Indian Creek (Allen and Anderson Counties)

Labette Creek $^{4}$ (Labette and Neosho Counties)

$\begin{array}{rll}-- & 19 & 60 \\ 5 & 31 & 50 \\ 21 & 17 & 21 \\ 19 & 22 & 20 \\ 5 & 24 & 44\end{array}$

$\begin{array}{rrr}23 & 28 & 17 \\ -- & 5 & 14 \\ 13 & 21 & 30 \\ 25 & 18 & 18 \\ 20 & 28 & 29\end{array}$

46
59
35
17
11

$\begin{array}{rll}10 & -- & 13 \\ 11 & -- & 13 \\ 7 & -- & 17 \\ 5 & -- & 25 \\ -- & -- & 25 \\ & & \\ -- & -- & 26 \\ -- & -- & 25 \\ 4 & -- & 16 \\ 2 & -- & 25\end{array}$

26 25

$\begin{array}{rrr}9 & -- & 18 \\ 16 & 4 & 15 \\ 52 & 14 & 6 \\ 23 & 5 & 14 \\ 36 & 13 & 8 \\ 41 & 12 & 7\end{array}$

$\begin{array}{llllll}4 & 49 & 32 & 15 & - & 16\end{array}$

$\begin{array}{lll}21 & -- & 11 \\ 12 & 2 & 13 \\ 14 & 1 & 27 \\ 26 & 6 & 14 \\ 22 & 4 & 11\end{array}$

$\begin{array}{rrr}23 & 5 & 18 \\ 52 & 29 & 5 \\ 25 & 6 & 12 \\ 13 & 4 & 29 \\ 15 & 5 & 16\end{array}$


Table 6. Particle-size data for gravel in bar deposits sampled in selected tributaries to the Neosho River in Kansas, 2004.-Continued

[mm, millimeters; --, not present in sample]

\begin{tabular}{|c|c|c|c|c|c|c|c|c|}
\hline \multirow[b]{2}{*}{$\begin{array}{l}\text { Tributary } \\
\text { inspection site } \\
\text { number } \\
\text { (fig. 1) }\end{array}$} & \multicolumn{7}{|c|}{ Number of surficial particles in each particle-size class ${ }^{1}$} & \multirow[b]{2}{*}{$\begin{array}{c}\text { Median } \\
\text { particle size } \\
\quad(\mathrm{mm})\end{array}$} \\
\hline & $\begin{array}{c}\text { Large cobble } \\
\text { (128 to } 256 \\
\mathrm{~mm})\end{array}$ & $\begin{array}{c}\text { Small } \\
\text { cobble } \\
\text { (64 to } 128 \mathrm{~mm} \text { ) }\end{array}$ & $\begin{array}{c}\text { Very } \\
\text { coarse } \\
\text { gravel } \\
\text { (32 to } 64 \mathrm{~mm})\end{array}$ & $\begin{array}{c}\text { Coarse } \\
\text { gravel } \\
\text { (16 to } 32 \mathrm{~mm} \text { ) }\end{array}$ & $\begin{array}{c}\text { Medium } \\
\text { gravel } \\
\text { (8 to } 16 \mathrm{~mm} \text { ) }\end{array}$ & $\begin{array}{c}\text { Fine } \\
\text { gravel } \\
(4 \text { to } 8 \mathrm{~mm})\end{array}$ & $\begin{array}{c}\text { Very } \\
\text { fine } \\
\text { gravel } \\
\text { (2 to } 4 \mathrm{~mm})\end{array}$ & \\
\hline \multicolumn{9}{|c|}{ Labette Creek $^{4}$ (Labette and Neosho Counties)_Continued } \\
\hline 32 & -- & -- & 5 & 28 & 37 & 27 & 3 & 12 \\
\hline 33 & 1 & 6 & 5 & 34 & 32 & 17 & 5 & 14 \\
\hline 34 & 1 & 2 & 7 & 39 & 25 & 18 & 8 & 14 \\
\hline \multicolumn{9}{|c|}{ Lightning Creek (Cherokee and Crawford Counties) } \\
\hline 1 & -- & -- & 5 & 48 & 35 & 12 & -- & 16 \\
\hline 3 & 1 & 7 & 19 & 24 & 26 & 17 & 6 & 16 \\
\hline 4 & -- & 1 & 3 & 17 & 36 & 34 & 9 & 8 \\
\hline 6 & -- & -- & 1 & 6 & 34 & 53 & 6 & 7 \\
\hline 10 & -- & -- & 1 & 7 & 35 & 48 & 9 & 7 \\
\hline 12 & -- & 1 & 3 & 14 & 34 & 39 & 9 & 8 \\
\hline 16 & -- & 4 & 8 & 27 & 32 & 21 & 8 & 11 \\
\hline 19 & -- & -- & 4 & 22 & 38 & 27 & 9 & 9 \\
\hline 22 & 2 & 2 & 6 & 18 & 38 & 28 & 6 & 10 \\
\hline \multicolumn{9}{|c|}{ Long Creek (Coffey County) } \\
\hline 4 & -- & -- & -- & 18 & 39 & 37 & 6 & 9 \\
\hline 7 & 11 & 28 & 37 & 16 & 5 & 2 & 1 & 53 \\
\hline \multicolumn{9}{|c|}{ Owl Creek (Allen and Woodson Counties) } \\
\hline 2 & -- & -- & 21 & 67 & 11 & 1 & -- & 22 \\
\hline 3 & 1 & 17 & 60 & 21 & 1 & -- & -- & 41 \\
\hline 9 & -- & -- & -- & 1 & 46 & 52 & 1 & 7 \\
\hline 10 & -- & -- & 1 & 19 & 68 & 12 & -- & 12 \\
\hline 13 & -- & 1 & 4 & 41 & 47 & 7 & -- & 14 \\
\hline 14 & -- & -- & 2 & 22 & 54 & 22 & -- & 12 \\
\hline 16 & -- & -- & -- & 1 & 57 & 42 & -- & 8 \\
\hline 17 & -- & -- & 2 & 49 & 49 & -- & -- & 16 \\
\hline \multicolumn{9}{|c|}{ Turkey Creek (Coffey and Woodson Counties) } \\
\hline 3 & -- & 1 & 19 & 55 & 24 & 1 & -- & 20 \\
\hline 4 & -- & -- & -- & 11 & 38 & 48 & 3 & 7 \\
\hline 7 & -- & 1 & 36 & 53 & 9 & 1 & -- & 27 \\
\hline \multicolumn{9}{|c|}{ Village Creek (Neosho and Wilson Counties) } \\
\hline 1 & -- & -- & 1 & 41 & 45 & 13 & -- & 14 \\
\hline 4 & -- & -- & 11 & 45 & 32 & 12 & -- & 16 \\
\hline
\end{tabular}

${ }^{1}$ Particle-size classes from Gordon and others (1992). Particles with an intermediate axis length equivalent to the size break between two classes were assigned to the larger class.

${ }^{2}$ Sample included one small boulder.

${ }^{3}$ Includes the tributary Walnut Creek.

${ }^{4}$ Includes the tributaries Deer Creek, Hackberry Creek, and Little Labette Creek. 